\title{
A Study of Ventilation \\ Measurement in an Office Building
}
$\mathrm{QC}$
100
. $\mathrm{U} 56$
4905
1992

U. S. Department of Commerce

National Institute of Standards and Technology

Building and Fire Research Laboratory

Gaithersburg, MD 20899
Prepared for:

Bonneville Power Administration

Commercial Technology Section

Portland, OR 97208 



\section{A Study of Ventilation Measurement in an Office Building}

W. Stuart Dols

Andrew K. Persily

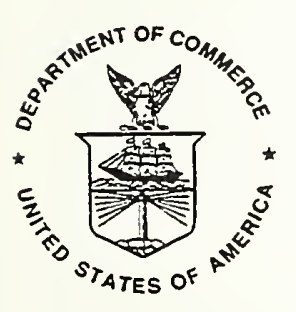

October 1992

U. S. Department of Commerce

Barbara H. Franklin, Secretary

National Institute of Standards and Technology

John W. Lyons, Director

Building and Fire Research Laboratory

Gaithersburg, MD 20899
Prepared for:

Bonneville Power Administration Commercial Technology Section

Portland, OR 97208 



\section{ABSTRACT}

The National Institute of Standards and Technology has conducted a study of ventilation and ventilation measurement techniques in the Bonneville Power Administration (BPA) Building in Portland, Oregon. The project involved the comparison of outdoor air ventilation measurement techniques for relative accuracies and an examination of changes in building ventilation rates over time. The following measurement techniques were compared: tracer gas decay measurements of whole building air change rates, the determination of air change rates based on peak carbon dioxide $\left(\mathrm{CO}_{2}\right)$ concentrations, the determination of percent outdoor air intake using tracer gas (sulfur hexafluoride and occupant-generated $\mathrm{CO}_{2}$ ), and direct airflow rate measurements within the air handling system. In addition, air change rate measurements made with an automated tracer gas decay system approximately three years apart were compared.

The major findings of the study are as follows. Airflow rates were measured in the air handling system ductwork using pitot tube, hot-wire anemometer, and vane anemometer traverses, and good agreement was obtained between the different techniques. While accurate determinations of percent outdoor air intake were achieved using tracer gas techniques, the use of $\mathrm{CO}_{2}$ detector tubes yielded unreliable results. Reliable determinations of ventilation rates per person were made based on $\mathrm{SF}_{6}$ decay and direct airflow rate measurements but the use of peak $\mathrm{CO}_{2}$ concentrations led to inaccuracies, i.e., the overprediction of ventilation rates by as much as $100 \%$. The measured values of the whole building air change rates, and their dependence on outdoor air temperature, did not change significantly over a three year period. The minimum air change rates were above the building design value and ASHRAE Standard 62-1981, the standard on which the design was based, but the minimum rates were below the minimum recommendation given in Standard 62-1989. The whole building air change rate under minimum outdoor air intake conditions was determined to be twice the outdoor air intake rate provided by the minimum outdoor air intake fans. The additional air change under minimum outdoor air intake conditions was due primarily to leakage through the main outdoor air intake dampers.

KEY WORDS: airflow, building performance, carbon dioxide, commercial building, indoor air quality, measurements, office building, tracer gas, ventilation 



\section{TABLE OF CONTENTS}

ABSTRACT

1 INTRODUCTION 1

2 BACKGROUND

2.1 Building Description 2

2.2 Installation of Test Equipment 5

3 MEASUREMENT METHODS

$\begin{array}{lll}3.1 & \text { Whole Building Air Change Rates } & 7\end{array}$

3.2 Direct Measurement of Ventilation System Airflows 7

3.3 Percent Outdoor Air Intake Rate 8

3.4 Ventilation Rate per Person 9

4 RESULTS

$\begin{array}{lll}\text { 4.1 Whole Building Air Change Rates } & 12\end{array}$

4.2 Direct Measurement of Ventilation System Airflows 14

4.3 Percent Outdoor Air Intake Rate 17

4.3.1 Percent Outdoor Air: $\mathrm{SF}_{6}$ and $\mathrm{CO}_{2}$ Automated 17

4.3.2 Percent Outdoor Air: $\mathrm{CO}_{2}$ Detector Tubes 20

4.3.3 Percent Outdoor Air: Direct Airflow Measurement 22

4.4 Ventilation Rate per Person

4.4.1 Ventilation Rate per Person: $\mathrm{SF}_{6}$ Automated 23

4.4.2 Ventilation Rate per Person: Peak $\mathrm{CO}_{2}$ Automated 24

4.4.3 Ventilation Rate per Person: Peak $\mathrm{CO}_{2}$ Detector Tubes 25

4.4.4 Ventilation Rate per Person: Peak $\mathrm{CO}_{2}$ Air Sample Bags 25

4.4.5 Ventilation Rate per Person: Multiplicative Method 25

$4.5 \mathrm{CO}_{2}$ Build-up Analysis $\quad 26$

5 DISCUSSION

$\begin{array}{lll}5.1 & \text { Measurement Results } & 27\end{array}$

5.1.1 Direct Measurement of Ventilation System Airflows 27

5.1.2 Percent Outdoor Air Intake $\quad 27$

$\begin{array}{ll}\text { 5.1.3 Ventilation Rate per Person } & 29\end{array}$

$\begin{array}{lll}5.2 & \text { Measurement Issues } & 32\end{array}$

6 SUMMARY AND CONCLUSIONS 34

7 ACKNOWLEDGMENTS 36

8 REFERENCES 

Building ventilation systems are designed to provide sufficient levels of outdoor air to the building, to remove contaminants generated within the space and to provide an environment that is thermally acceptable to the building occupants. The design of these systems is based on ventilation standards that specify minimum levels of ventilation for occupant health and comfort. It has become increasingly apparent that design values for ventilation rates are not always realized in practice both when the building is constructed and after the building has been in operation for some time [Persily 1989]. This realization, along with increased concerns about indoor air quality, has led to the need for on-site assessment of building ventilation rates. The requirement for on-site assessment includes the need for practical and reliable procedures for making field measurements of building ventilation rates that are accessible to a range of engineering practitioners.

In order to assess different approaches for evaluating ventilation system performance, The National Institute of Standards and Technology (NIST) has conducted a study of ventilation and ventilation measurement techniques in the Bonneville Power Administration (BPA) Building in Portland, Oregon. The project involved two ventilation measurement issues: the comparison of ventilation measurement techniques and changes in building ventilation rates over time. Six ventilation measurement methods were studied in the comparison: 1) whole building ventilation rates determined by automated tracer gas (sulfur hexafluoride, $\mathrm{SF}_{6}$ ) decay, 2) whole building ventilation rates based on peak carbon dioxide $\left(\mathrm{CO}_{2}\right)$ concentration, 3) percent outdoor air using $\mathrm{SF}_{6}$ as a tracer gas, 4) percent outdoor air using an automated infrared $\mathrm{CO}_{2}$ monitoring system, 5) percent outdoor air using $\mathrm{CO}_{2}$ detector tubes and 6) direct airflow rate measurements in HVAC ducts. Also, two sets of building ventilation rate measurements obtained with the automated tracer gas system were compared. One set of measurements was made between September 1987 and July 1989 [Grot et al. 1989] and the other was collected as part of this study from July 1991 to February 1992.

During this project whole building air change rates were monitored continuously with an automated tracer gas decay system. Percent outdoor air intake rates were also monitored continuously with an automated $\mathrm{CO}_{2}$ monitoring system and the $\mathrm{SF}_{6}$ system. During this period, daily peak values of $\mathrm{CO}_{2}$ were used to calculate ventilation rates per person. Two weeks of intensive measurements of direct airflow rates and $\mathrm{CO}_{2}$ concentrations were performed simultaneously with the automated monitoring in order to compare various methods of assessing whole building ventilation rates. These methods were compared in terms of accuracy, ease of use and the level of effort required to implement them. 


\subsection{Building Description}

The BPA building is a seven story office building with a one story basement and a two story underground parking garage. The conditioned office space within the building has a floor area of approximately $32,500 \mathrm{~m}^{2}\left(350,000 \mathrm{ft}^{2}\right)$ and a volume of $114,000 \mathrm{~m}^{3}\left(4,030,000 \mathrm{ft}^{3}\right)$, assuming an average ceiling height of $3.5 \mathrm{~m}(11.5 \mathrm{ft})$ including the return air plenum. A breezeway connects this building to another office building on the first floor level, and a kitchen and dining room are attached at this level also (floor plans are contained in Grot et al. 1989). A penthouse mechanical room houses the main HVAC systems, consisting of three large variable air volume (VAV) systems, one serving the center of the building and the others serving the east and west sides. There are also several smaller air handling systems located on and serving the B1 level.

Sketches of the three main air handling systems are shown in Figures 1, 2 and 3. All three of the main air handling systems are basically the same, with some differences in physical layout and control parameter set-points. One of the major differences is that there is no duct between the outdoor air intake grille and the outdoor air intake dampers of the East mechanical system. Each system consists of two "cold" supply fans (SFC) that work in parallel, one "hot" supply fan (SFH), a return fan (RF) and a minimum outdoor air handling unit (AHU). The fans are designated in order of supply fans cold, supply fan hot, return fan and minimum outdoor air fan for the Center, East and West systems as follows: Center) SFC-1\&2, SFH-1, RF-6 and AHU-10; East) SFC-3\&4, SFH-2, RF-7 and AHU-11; West) SFC$5 \& 6, \mathrm{SFH}-3, \mathrm{RF}-8$ and AHU-12. The design supply air capacity of each system is approximately $47,200 \mathrm{~L} / \mathrm{s}(100,000 \mathrm{cfm})$ and the minimum outdoor air intake fan capacity is $2,000 \mathrm{~L} / \mathrm{s}(4,200 \mathrm{cfm})$ per system, which is about $4 \%$ of the supply air capacity. Based on the building volume, the minimum design outdoor air intake rate is 0.19 air changes per hour (ach) or $0.18 \mathrm{~L} / \mathrm{s}^{\bullet} \mathrm{m}^{2}\left(0.036 \mathrm{cfm} / \mathrm{ft}^{2}\right)$, and the maximum supply airflow capacity is 4.5 ach or $4.4 \mathrm{~L} / \mathrm{s} \cdot \mathrm{m}^{2}\left(0.86 \mathrm{cfm} / \mathrm{ft}^{2}\right)$. An estimate of 2,000 building occupants yields minimum and maximum per person design ventilation rates of $3 \mathrm{~L} / \mathrm{s}(6.3 \mathrm{cfm})$ per person and $70 \mathrm{~L} / \mathrm{s}(150 \mathrm{cfm})$ per person. This building was designed to comply with ASHRAE Standard 62-1981, which contained a minimum outdoor air intake requirement of $2.5 \mathrm{~L} / \mathrm{s}(5 \mathrm{cfm})$ per person in office space with no smoking present [ASHRAE 1981]. This requirement corresponds to an air change rate of approximately 0.15 ach for this building. ASHRAE Standard 62-1989 contains a minimum outdoor air requirement for office space of $10 \mathrm{~L} / \mathrm{s}(20 \mathrm{cfm})$ per person [ASHRAE 1989a] which corresponds to an air change rate of about 0.6 ach for this building. 


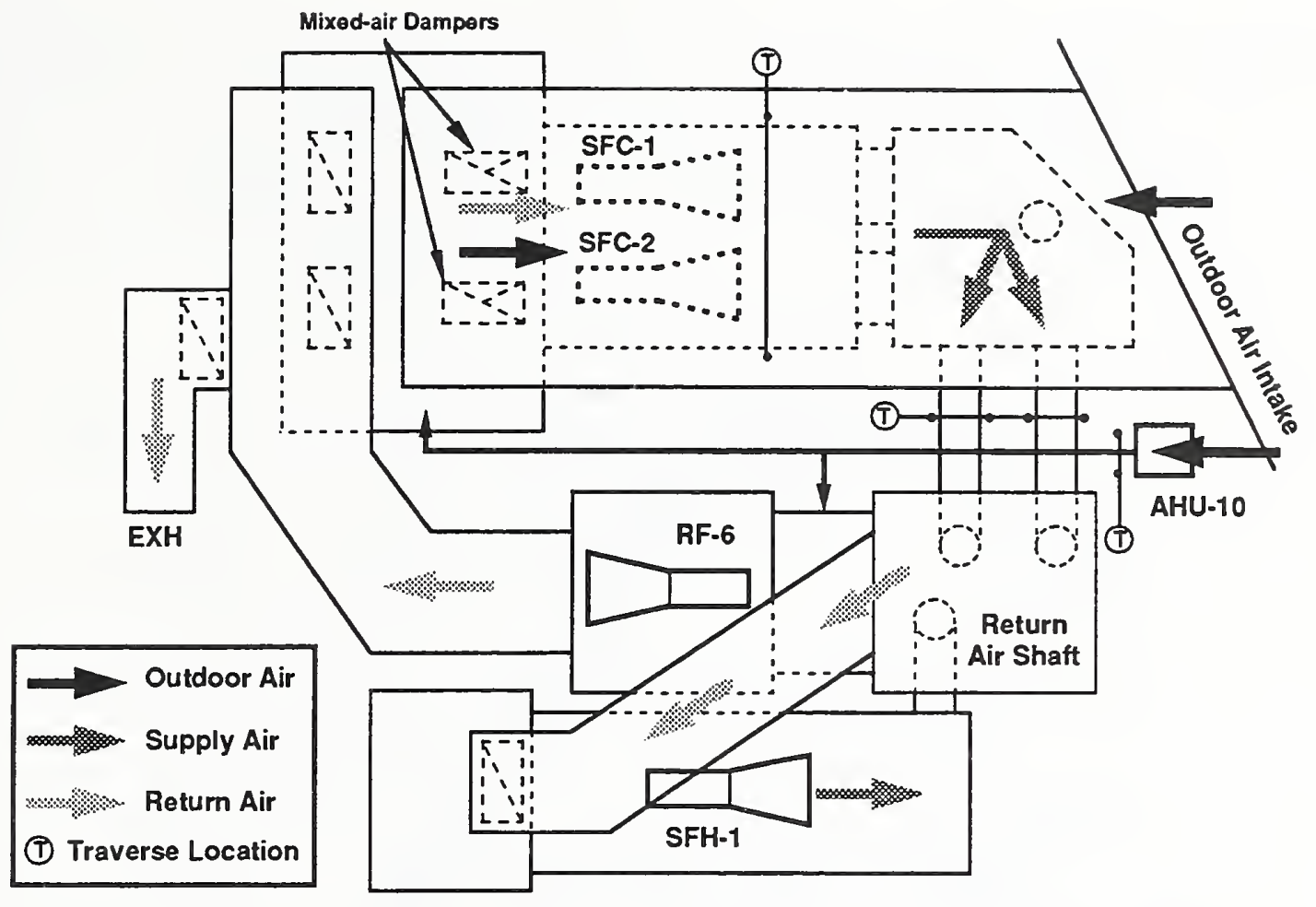

Figure 1: Schematic of Center mechanical system

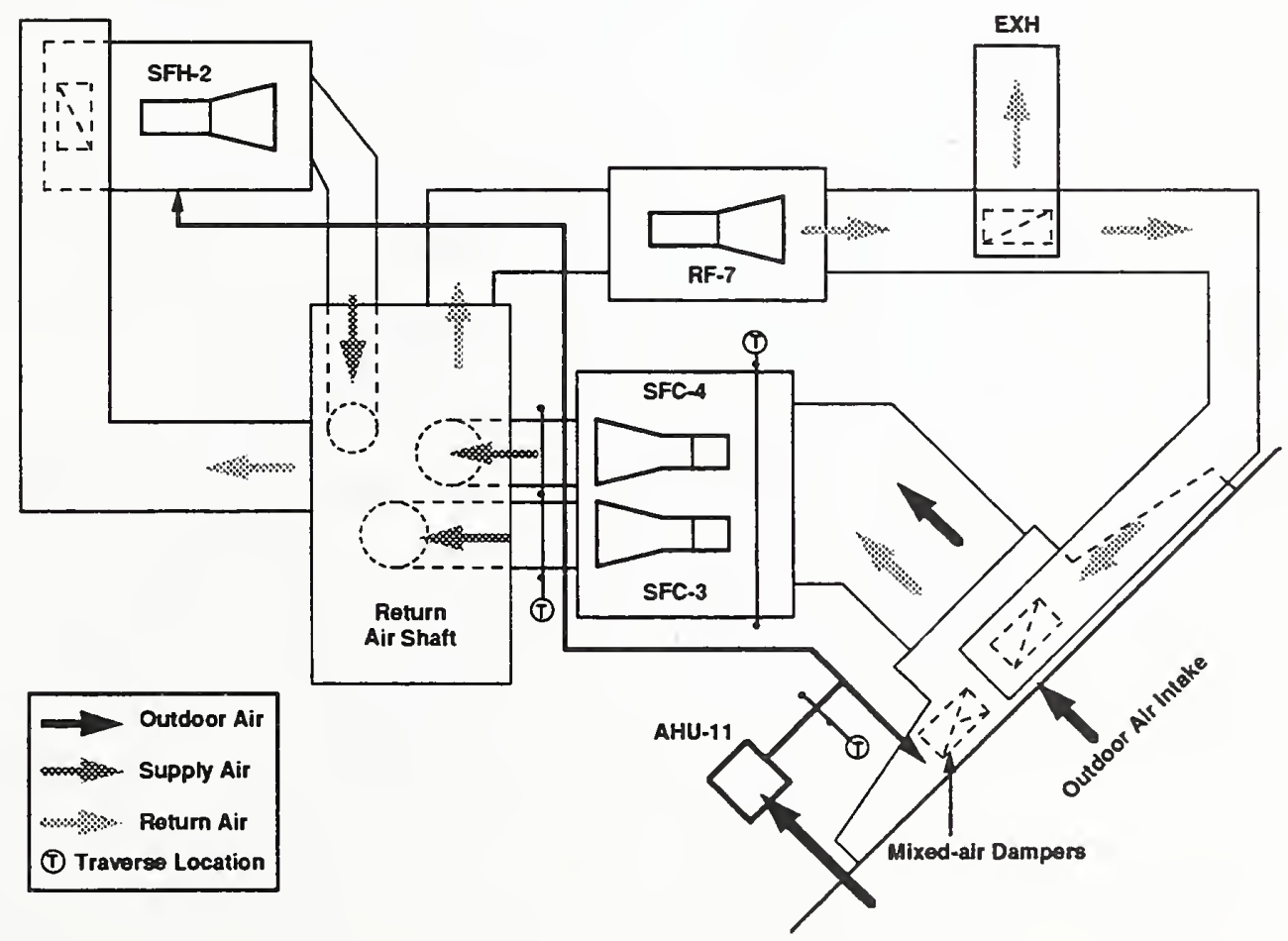

Figure 2: Schematic of East mechanical system 


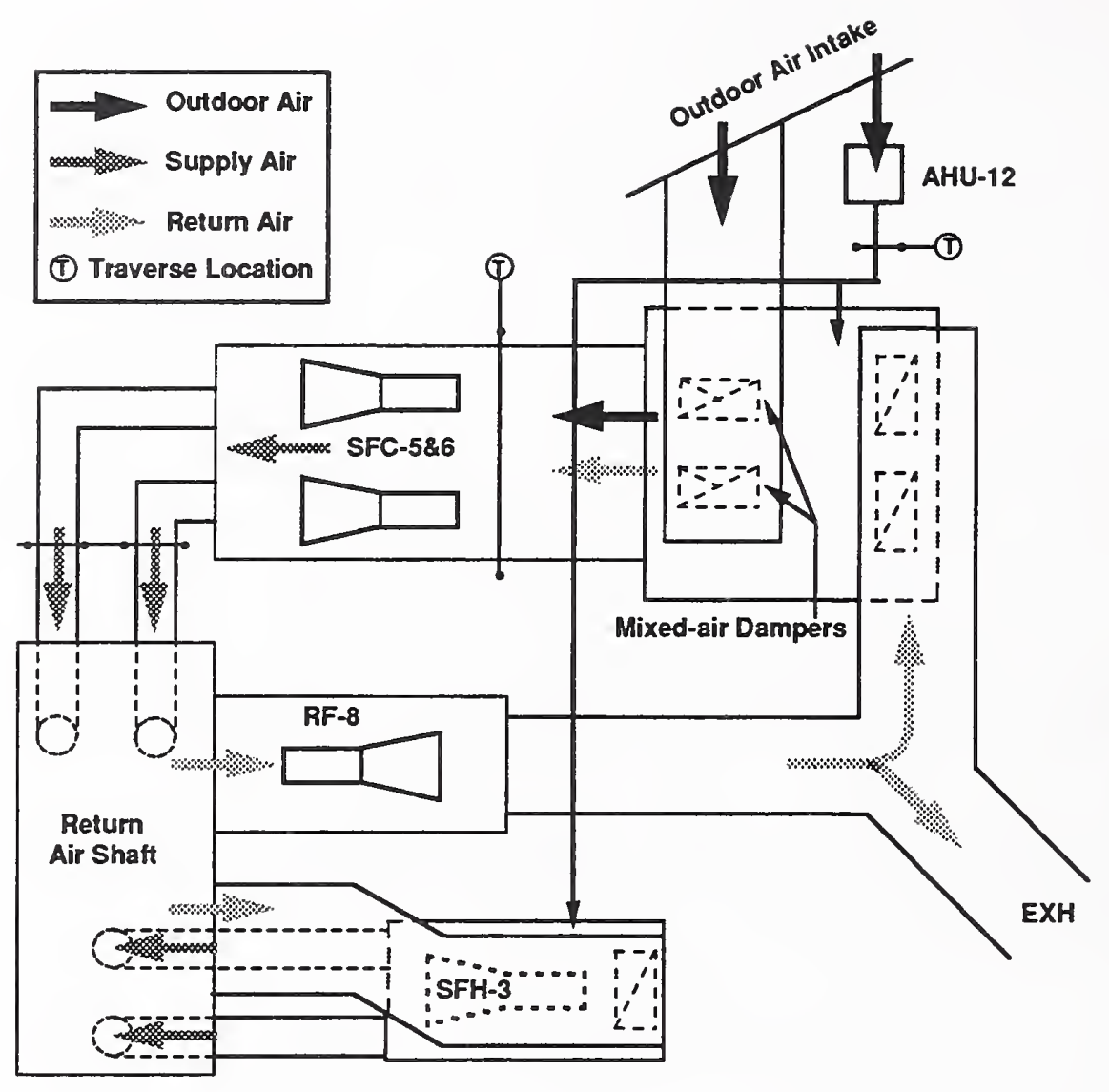

Figure 3: Schematic of West mechanical system

During building occupancy, the minimum outdoor air fans run continuously to provide the design minimum of outdoor air, and the supply fans use variable pitch fan blades to modulate airflow rate based on supply air demand in the occupied space. Supply air demand is controlled by terminal units located above the ceilings of the occupied space, which modulate air supply rates depending on the temperature in the zone being served by the terminal unit. As more units open, requiring additional supply airflow, the associated supply fan blades adjust to increase the airflow and maintain a supply static pressure set point in the main supply ducts.

An economizer system modulates the outdoor air intake rate through the "cold" supply fan system during mild weather by modulating the outdoor air intake (mixedair) damper position. Control parameters are programmed into the automated HVAC management system to obtain the desired system performance. Figure 4 is a sketch of the outdoor air intake control strategy for this building. Three set-points are used in the control of the mixed-air damper position. $T_{\text {off }}$ is the economizer shut-off temperature set-point. When the outdoor air temperature is above $\mathrm{T}_{\text {off }}$, the mixed-air dampers are closed because the outdoor air is too warm to use for cooling, and the chillers are used to meet the cooling load. When the outdoor air temperature is below a minimum level, $T_{\min }$, the mixed-air dampers close and the intake rate is again at the minimum level. $T_{\text {mix }}$ is the mixed air set-point temperature. Mixed air refers to the 
mixture of outdoor and return air upstream of the cooling coils. When the outdoor air temperature is between $\mathrm{T}_{\text {off }}$ and $\mathrm{T}_{\text {mix }}$, the mixed-air dampers are in the $100 \%$ open position. Modulation of the mixed-air damper occurs when the outdoor air temperature is between $T_{\min }$ and $T_{\text {mix }}$. Operation within this range between $T_{\min }$ and $T_{\text {off }}$ is referred to as the economizer cycle.

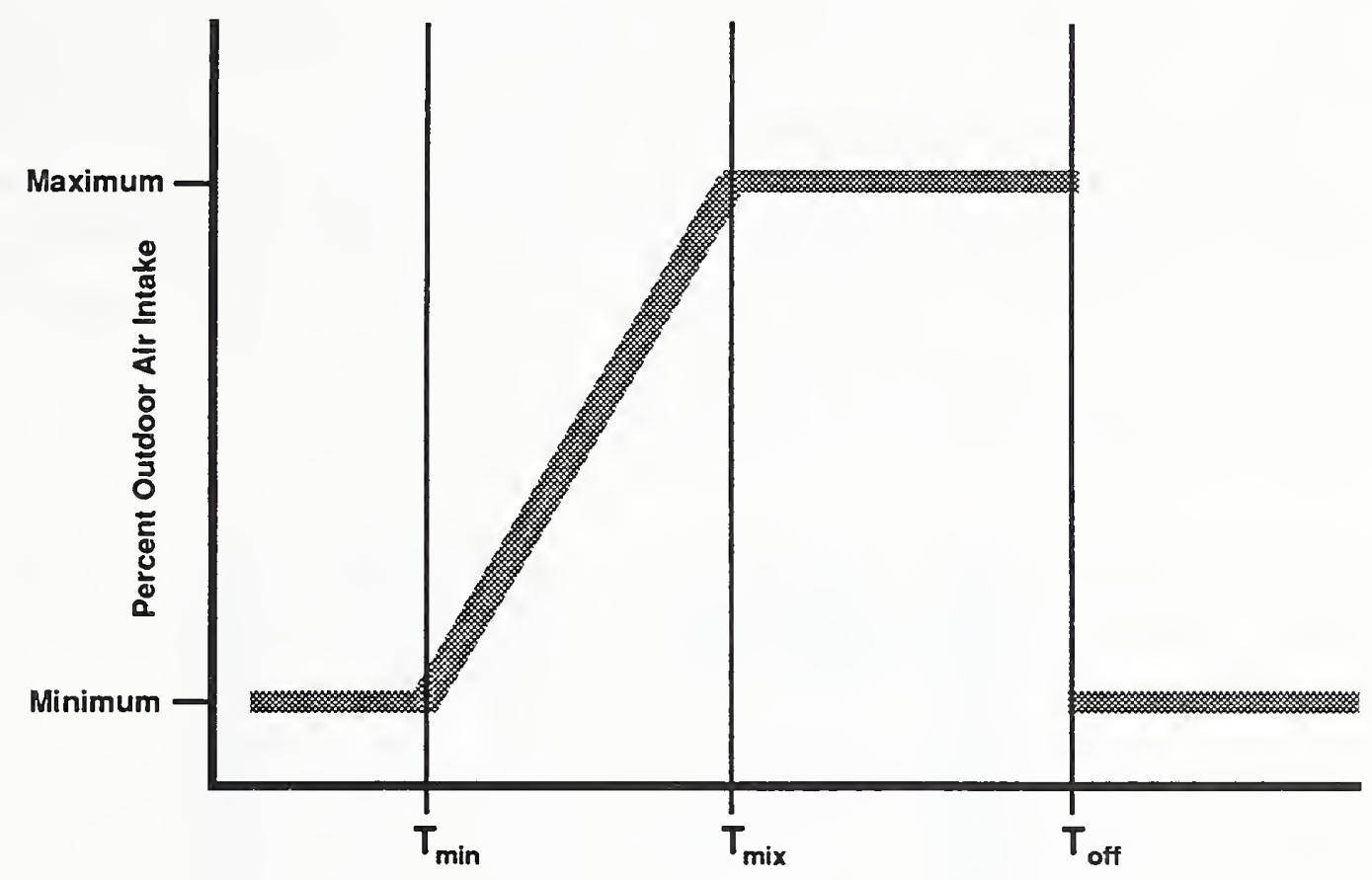

Outdoor Temperature

Figure 4: Outdoor air intake control strategy

\subsection{Installation of Test Equipment}

During July 1991, an automated $\mathrm{SF}_{6}$ tracer gas measurement system, an automated infrared $\mathrm{CO}_{2}$ monitoring system and a sample pump system were reinstalled in the building diagnostic center that was used during the previous study done by NIST [Grot et al. 1989]. Figure 5 shows a schematic of the $\mathrm{SF}_{6}$ and $\mathrm{CO}_{2}$ measurement systems. Air sample tubes of $0.095 \mathrm{~mm}$ (3/8 in.) OD polyethylene are connected to air sample pumps that pull air from the air sample locations. The output of these pumps is connected to the 10 -channel $\mathrm{SF}_{6}$ analyzer that is controlled by a microcomputer-based data acquisition and control system. This system also controls the tracer gas injection system which releases $\mathrm{SF}_{6}$ into the building supply fans through $0.032 \mathrm{~mm}(1 / 8 \mathrm{in}$.) OD nylon tubing.

The automated tracer gas measurement system was developed at NIST. This microcomputer-based system controls the tracer gas injection, air sampling and tracer gas concentration analysis, monitors the interior air temperatures, weather conditions and fan operation status, and records the test data. The system operates unattended for 
periods up to several weeks, with periodic attention required to change data disks and compressed gas supplies and to check instrument calibrations. In these measurements, $\mathrm{SF}_{6}$ is used as the tracer gas in the parts per billion ( $\mathrm{ppb}$ ) range.

The $\mathrm{CO}_{2}$ system employs the same air sample tubes and pumps used in the $\mathrm{SF}_{6}$ decay tests, with a portion of the pump output directed to the $\mathrm{CO}_{2}$ measurement system. This system employs an infrared absorption analyzer for determining $\mathrm{CO}_{2}$ concentrations and a microcomputer to control the air sampling and to record the data. $\mathrm{CO}_{2}$ concentrations were determined once every ten minutes at each of the same sample locations that the tracer gas decay system was monitoring. The $\mathrm{CO}_{2}$ monitor has a range of 0 to 2500 parts per million (ppm) and is accurate to within $0.5 \%$ of full scale.

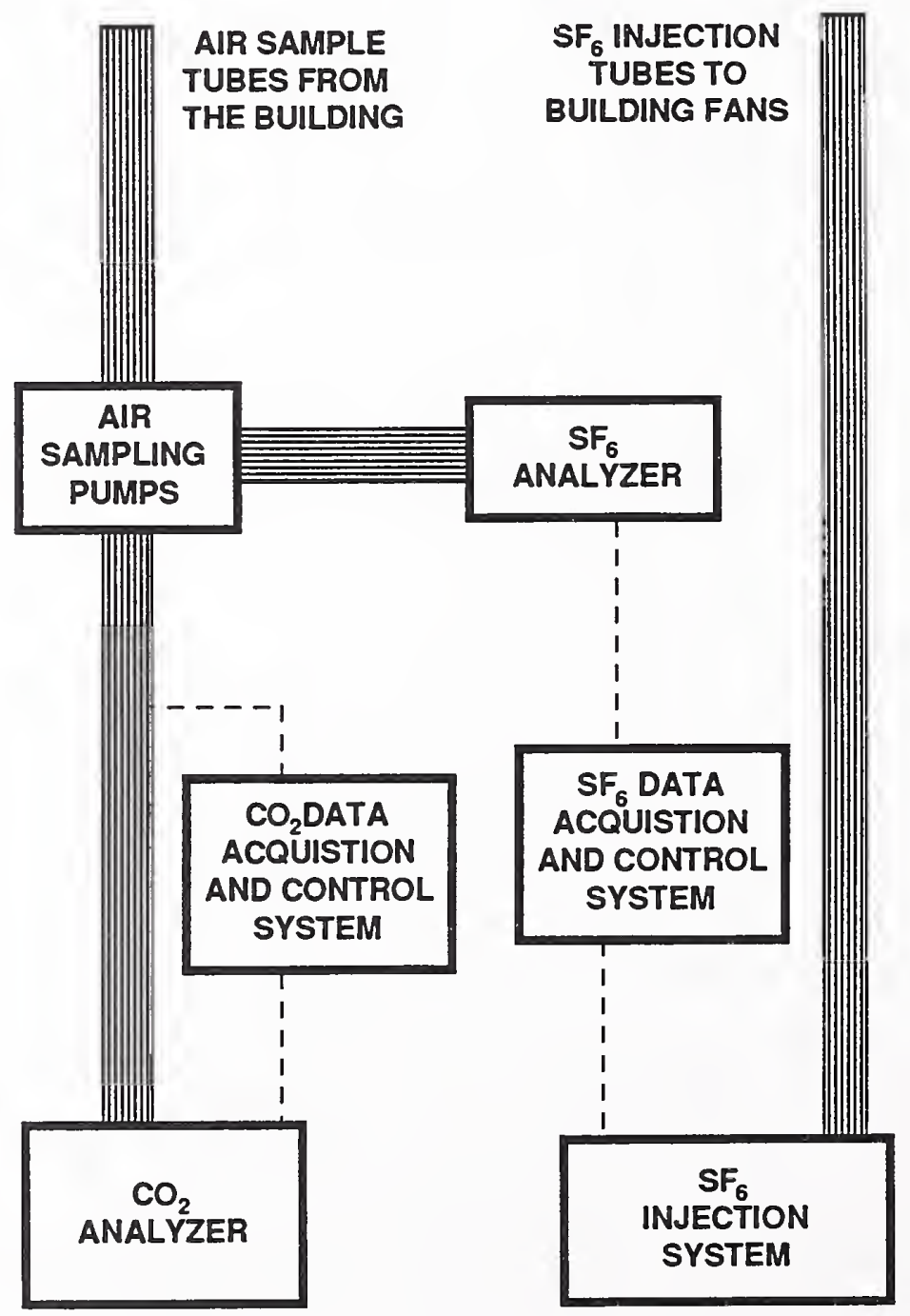

Figure 5: Schematic of $\mathrm{SF}_{6}$ and $\mathrm{CO}_{2}$ automated monitoring systems 


\subsection{Whole Building Air Change Rates}

Whole building air change rates were determined using the tracer gas decay method [ASTM 1983]. The automated tracer gas decay system injected $\mathrm{SF}_{6}$ into the supply air streams of the building's air handlers every three hours. Tracer gas concentrations were then sampled in 10 locations, with each sample location being monitored once every ten minutes. The seven injection locations were the Center, East and West "cold" supply fans, and four air handlers serving the B1 level. An injection tube carried a metered amount of tracer gas to the supply air stream of the individual air handlers. Tracer gas injection flow rates were based on the volume served by each individual air handler. The locations being sampled were the "cold" supplies and returns of the Center, East and West systems; the returns of the four air handlers serving the $\mathrm{B} 1$ level, the outdoor air, and the diagnostic center which contained the test equipment.

Whole building air change rates were determined by averaging the decay rates of the three main return ducts. The accuracy of these air change rate determinations is a function of the uniformity of tracer gas concentration within the building and the calibration of the $\mathrm{SF}_{6}$ analyzer. Based on the assumption of perfect mixing and the calibration of the $\mathrm{SF}_{6}$ analyzer, the accuracy of the air change rates is estimated to be about $10 \%$ of the measured value. The tracer gas decay technique determines the total air change rate of the building, including both intentional intake through the ventilation system and unintentional air leakage through the envelope. Previous studies have shown that air change rates due to infiltration can be on the order of magnitude of mechanical ventilation rates [Persily and Norford 1987].

\subsection{Direct Measurement of Ventilation System Airflows}

Direct measurements of system supply and outdoor airflow rates were made during the weeks of 6 August 1991 and 13 January 1992. A hot wire anemometer, a vane anemometer and a pitot tube with a digital manometer were used during the first week in various locations of the three main systems in order to assess the speed and reliability of these methods for measuring airflow rates in this HVAC system. Both the hot wire and vane anemometers gave direct readings of velocity in $\mathrm{m} / \mathrm{s}(\mathrm{ft} / \mathrm{min}$ ), and the digital manometer used with the pitot tube gave velocity pressure readings in $\mathrm{Pa}$ (inches of water) which were converted to $\mathrm{m} / \mathrm{s}(\mathrm{ft} / \mathrm{min}$ ) at standard conditions. Duct traverses were performed using the hot wire anemometer and pitot tube in the main supply air ducts, the minimum outdoor air ducts and the economizer outdoor air intake ducts. Traverses were also performed inside the cold supply fan housings (fan boxes) using the hot wire anemometer and the vane anemometer. Traverse locations are indicated by an encircled letter " $T$ " in Figures 1 through 3. Measurement errors for these airflow rates, based on the precision of the measurement devices alone, were 
less than $3.0 \%$. This accuracy estimate does not include error due to the use of traverse locations which do not conform with recommended guidelines [ACGIH 1988].

The first week of measurements was performed with several objectives in mind: a comparison of velocity measurements with different devices at the same location, a comparison of measurements of the same airflow rate at different locations, a comparison of measured airflow rates versus design airflow rates, and the use of direct airflow rate measurements to determine percent outdoor air intake. The second week of testing concentrated on the determination of mechanical ventilation rates under minimum outdoor air intake conditions. Based on the results obtained during the first week of measurements, only the total supply airflow rates and the minimum outdoor airflow rates were measured during the second week of testing using the hot wire anemometer. During the second week, supply airflow rates were measured in the cold fan housings immediately downstream of the cooling coils, and duct traverses were performed downstream of the minimum outdoor air intake fans. During two days of the second week, the three main ventilation systems were operated at minimum outdoor air intake.

\subsection{Percent Outdoor Air Intake Rate}

Percent outdoor air intake rates were determined using four different methods: tracer gas balances employing the automated $\mathrm{SF}_{6}$ and automated $\mathrm{CO}_{2}$ systems, tracer gas balances based on $\mathrm{CO}_{2}$ detector tube measurements, and direct airflow measurements. When using tracer gas to determine percent outdoor air, a balance of the tracer gas $\left(\mathrm{SF}_{6}\right.$ or $\left.\mathrm{CO}_{2}\right)$ and airflow at each air handler was utilized. Based on the measured values of the supply, return and outdoor air tracer gas concentrations, percent outdoor air intake was determined by

$$
\% O A=\frac{C_{\text {return }}-C_{\text {supply }}}{C_{\text {return }}-C_{\text {outdoor }}}
$$

Equation 1 was used to determine percent outdoor air intake based on tracer gas concentrations obtained with the automated $\mathrm{SF}_{6}$ system, the automated $\mathrm{CO}_{2}$ system, and $\mathrm{CO}_{2}$ detector tubes. The detector tubes contain a substance which changes color when exposed to $\mathrm{CO}_{2}$ and have graduated markings on the side that indicate the concentration based on the length of substance that changes color. A hand-held volumetric piston pump is used to draw the air sample into the tube. Two sampling strategies were employed using the detector tubes [Ancker et al. 1989]. One sampling strategy was to measure the supply, return, and outdoor air concentrations successively, and then have three people read each tube. The other strategy was to have only one person read the tubes. Error values in the measured $\mathrm{CO}_{2}$ concentrations are assumed to equal $33 \mathrm{ppm}$ for the individual concentration readings using 3 pump strokes to perform a single measurement. The value of $33 \mathrm{ppm}$ is based only on the 
resolution of the graduated markings on the detector tube, assuming the user can resolve the tube readings within $100 \mathrm{ppm}$. Calibration errors in the detector tube readings could lead to larger uncertainties.

Direct airflow measurements to determine percent outdoor air intake were mostly performed under minimum outdoor air intake conditions. The percent outdoor air intake is simply the ratio of the measured outdoor air intake rate and the measured supply airflow rate. The supply airflow rates were measured upstream of the supply fans inside the fan housings. Under minimum outdoor air intake, the outdoor air intake rates were measured downstream of the minimum outdoor air intake fans. The percent outdoor air intake under economizer operation was determined by the direct airflow method on only one occasion because it required a great deal of time to perform a traverse of the large economizer outdoor air intake ducts. During the traverses of the economizer ducts, the supply airflow rate rarely remained constant, interfering with several attempts to make these measurements.

\subsection{Ventilation Rate per Person}

One of the objectives of this project was to compare different techniques for determining ventilation rates per person. Three methods were used to determine the outdoor air intake rate per person: tracer gas decay, peak $\mathrm{CO}_{2}$ levels, and direct measurement of the total supply airflow rate multiplied by the percent outdoor air intake rate (multiplicative method). The measurement of peak $\mathrm{CO}_{2}$ levels was performed using the automated $\mathrm{CO}_{2}$ system, $\mathrm{CO}_{2}$ detector tubes, and air sample bags filled using a portable pump and analyzed with the automated $\mathrm{CO}_{2}$ system analyzer. The determination of the per person ventilation rate by the multiplicative method employed the various methods to determine percent outdoor air intake described previously. The tracer gas and $\mathrm{CO}_{2}$ methods determine the ventilation rate due to both mechanical ventilation and envelope leakage. The multiplicative method only accounts for outdoor air intake through the mechanical system.

Whole building ventilation rates determined using the tracer gas decay method were based on the average of the decay rates measured in the return air ducts of the three main air handlers. In order to convert whole building ventilation rates in air changes per hour to ventilation rate per person, the whole building air change rate is multiplied by the building volume and divided by the number of building occupants, assumed to equal 2000.

Building ventilation rates were also estimated by measuring equilibrium or peak values of $\mathrm{CO}_{2}$ inside the building and the outdoor concentration. This method is based on a mass balance of $\mathrm{CO}_{2}$ within the building with a constant ventilation rate, a uniform and constant $\mathrm{CO}_{2}$ generation rate inside the building (i.e. constant occupancy), and a constant outdoor $\mathrm{CO}_{2}$ concentration [Persily and Dols 1990]. Under these assumptions the building ventilation rate is related to the equilibrium $\mathrm{CO}_{2}$ concentration inside the building by the following equation: 


$$
\mathrm{Q}_{\mathrm{p}}=\frac{\mathrm{G}_{\mathrm{p}}}{\left(\mathrm{C}_{\mathrm{eq}}-\mathrm{C}_{\mathrm{o}}\right)}
$$

where

$\mathrm{Q}_{\mathrm{p}}=$ the per person building ventilation rate $\left[\mathrm{m}^{3} / \mathrm{s}\right.$ per person],

$\mathrm{G}_{\mathrm{p}}=$ the per person $\mathrm{CO}_{2}$ generation rate (assumed equal to $5.3 \times 10^{-6} \mathrm{~m}^{3} / \mathrm{s}$ per person),

$\mathrm{C}_{\mathrm{eq}}=$ the indoor $\mathrm{CO}_{2}$ concentration at equilibrium,

$\mathrm{C}_{\mathrm{o}}=$ the outdoor $\mathrm{CO}_{2}$ concentration.

This method is also based on the assumption that the $\mathrm{CO}_{2}$ concentration is the same throughout the building and that the $\mathrm{CO}_{2}$ concentration has attained equilibrium.

The determination of ventilation rate per person using $\mathrm{CO}_{2}$ detector tubes is also based on Equation 2 and the associated assumptions. Detector tubes were used to measure ventilation rates per person on 15 and 16 January 1992. On the fifteenth, concentrations were measured in the return air ducts of the three main air handlers, and on the sixteenth they were measured in several locations within the occupied space.

Peak $\mathrm{CO}_{2}$ measurements were performed within the occupied space using portable hand held sample pumps and air sample bags and the infrared $\mathrm{CO}_{2}$ detector of the automated $\mathrm{CO}_{2}$ system. This was done only on 16 January 1992 at the same time as the $\mathrm{CO}_{2}$ detector tube measurements were being performed. Samples were collected over a period of about one hour which spanned the time at which the peak indoor concentration was expected to occur. The expected peak time was based on the automated $\mathrm{CO}_{2}$ data collected the previous day and verified by the automated data collected during the test. Air samples were collected at three locations on floors 1 through 7 , and an average of these sample concentrations was used as the equilibrium concentration. Outdoor air samples were also collected before and after the interior samples were collected, and the average of these values was used in the calculation.

When determining ventilation rates per person using the multiplicative method, supply airflow rates were measured using a hot wire anemometer in the supply fan housings as described in section 3.2 on direct airflow measurements. Percent outdoor air intake rates were measured using the $\mathrm{SF}_{6}$ and $\mathrm{CO}_{2}$ automated systems, $\mathrm{CO}_{2}$ detector tubes and direct airflow measurements of the minimum outdoor air intake fans. In the latter case, the multiplicative approach corresponds to the direct measurement of the outdoor air intake rate at the minimum outdoor air handler units. 


\section{5 $\mathrm{CO}_{2}$ Build-up Analysis}

While the peak $\mathrm{CO}_{2}$ measurement technique requires steady state conditions to exist, one can analyze the build-up in $\mathrm{CO}_{2}$ concentrations to determine ventilation rates. The build-up method is based on the transient analysis of $\mathrm{CO}_{2}$ as the concentration increases or builds up in the morning. The technique is based on a single-zone mass balance expressed in volumetric terms as

$$
\mathrm{V} \frac{\mathrm{dC}}{\mathrm{dt}}=\mathrm{Q}\left(\mathrm{C}_{\mathrm{o}}-\mathrm{C}\right)+\mathrm{G}
$$

where

$$
\begin{aligned}
& \mathrm{V}=\text { the building volume, } \\
& \mathrm{C}=\text { the interior } \mathrm{CO}_{2} \text { concentration, } \\
& \mathrm{t}=\text { time, } \\
& \mathrm{Q}=\text { the airflow rate into and out of the building, } \\
& \mathrm{C}_{\mathrm{o}}=\text { the outdoor } \mathrm{CO}_{2} \text { concentration, and } \\
& \mathrm{G}=\text { the generation rate of } \mathrm{CO}_{2} \text { within the building. }
\end{aligned}
$$

Assuming that $\mathrm{Q}, \mathrm{C}_{\mathrm{o}}$ and $\mathrm{G}$ are constant, and setting $\mathrm{C}$ ' equal to the difference between the indoor and outdoor $\mathrm{CO}_{2}$ concentration, the solution to Equation 3 can be expressed as

where

$$
C^{\prime}=C_{\text {eq }}^{\prime}+\left(C_{\text {init }}^{\prime}-C_{\text {eq }}^{\prime}\right) e^{-I t}
$$

$$
\begin{aligned}
& C^{\prime}=\text { the equilibrium value of } C^{\prime}, G / Q, \\
& \begin{aligned}
C^{\prime}{ }^{\prime} & =C-C_{o} \text { at } t=0, \text { and } \\
I^{\text {init }} & =Q / N \text {, the building air change rate. }
\end{aligned}
\end{aligned}
$$

Based on the time history of the $\mathrm{CO}_{2}$ concentration inside the return air ducts, nonlinear regression techniques were used to solve for the parameters $C^{\prime}{ }_{\text {eq }}, C^{\prime}{ }_{\text {init }}$ and I. The value of I can be converted to the ventilation rate per person based on the building volume and the number of occupants. In addition, an average $\mathrm{CO}_{2}$ generation rate per person can be determined by the following equation.

$$
\mathrm{G}_{\mathrm{p}}=\frac{\mathrm{C}_{\mathrm{eq}} \mathrm{IV}}{\# \text { of occupants }}
$$




\subsection{Whole Building Air Change Rates}

The automated tracer gas system was used to measure whole building air change rates in a previous study from September 1987 to July 1989 [Grot et al. 1989] and in this study from July 1991 to January 1992. This enabled an assessment of any changes in the operation and performance of the ventilation system since the previous study was performed. Figure 6 shows the whole building air change rates as determined by the automated $\mathrm{SF}_{6}$ system for the old and new sets of data. The new data is very similar to the data collected in the previous study, indicating that for these weather conditions, i.e., outdoor temperatures between 12 and $32^{\circ} \mathrm{C}\left(54\right.$ and $90^{\circ} \mathrm{F}$ ), the building ventilation system is operating as it was during the period of September 1987 to July 1989. These two data sets provide the first opportunity to assess changes in the ventilation characteristics of a building over such a long period of time.

Figure 6 shows the design minimum air change rate and the air change rates corresponding to the minimums recommended in ASHRAE Standard 62-1981 $(2.5 \mathrm{~L} / \mathrm{s}$ per person, $5 \mathrm{cfm}$ per person) and ASHRAE Standard 62-1989 (10 L/s per person, 20 cfm per person) based on the building occupancy of 2000 people. The average minimum air change rate measured using tracer gas decay for the new data set is 0.45 ach, about twice the design minimum of 0.19 ach. The maximum measured air change rate shown in Figure 6 is 2.2 ach, about one half of the design capacity.

Figure 7 shows some of the new whole building ventilation data and outdoor temperature plotted against the time of day for a two week period beginning at the end of July 1991. Under these conditions of outdoor temperature, minimum ventilation rates tended to occur between the hours of 12 noon and 5 p.m. when the outdoor temperature was at its highest point and above the economizer shut-off set-point temperature. In the morning the outdoor air temperature was low enough to allow the use of outdoor air for cooling, and the outdoor air intake rate increased to 1.0 ach or more. 


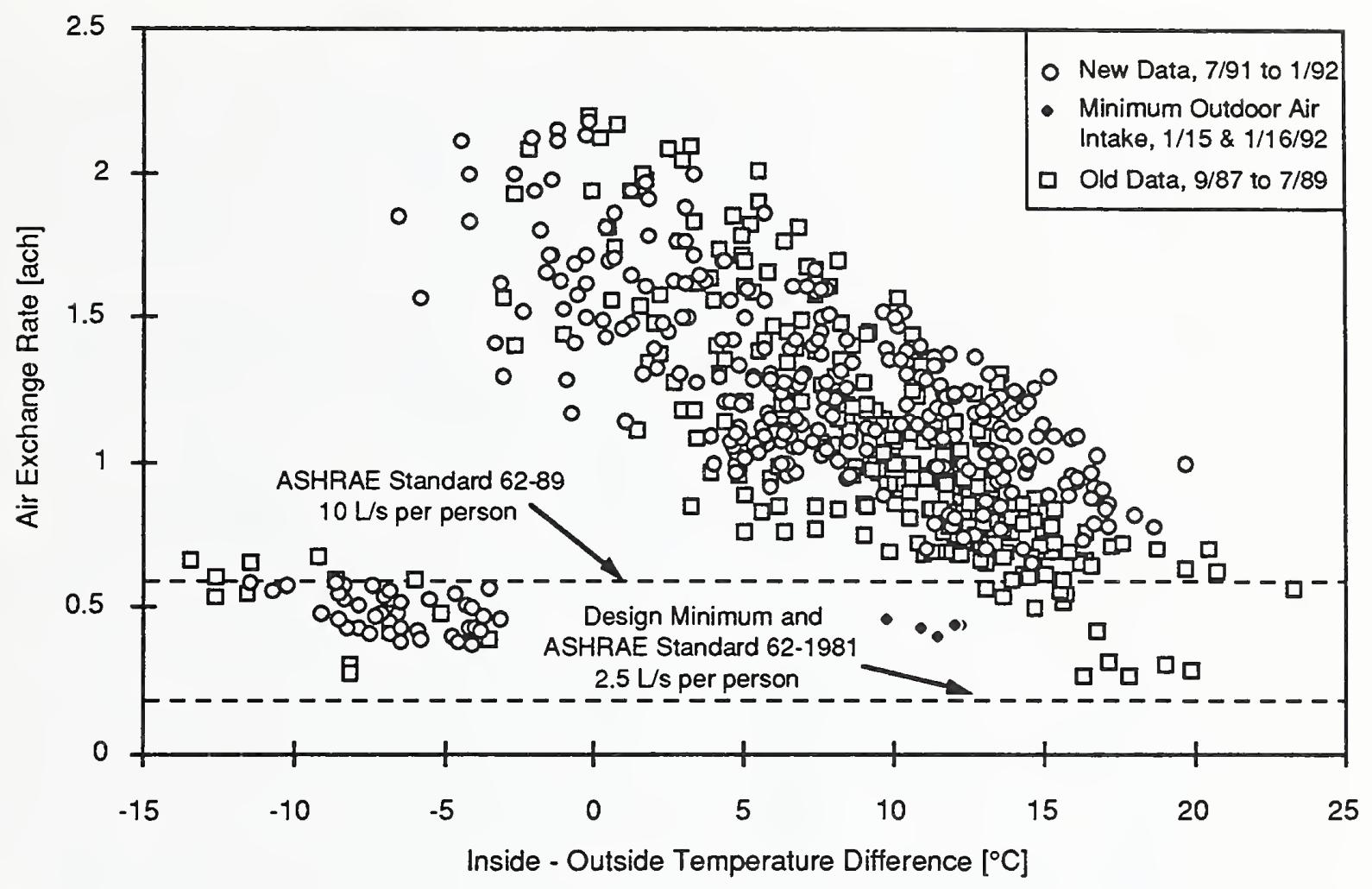

Figure 6: Building air change rates for old and new data

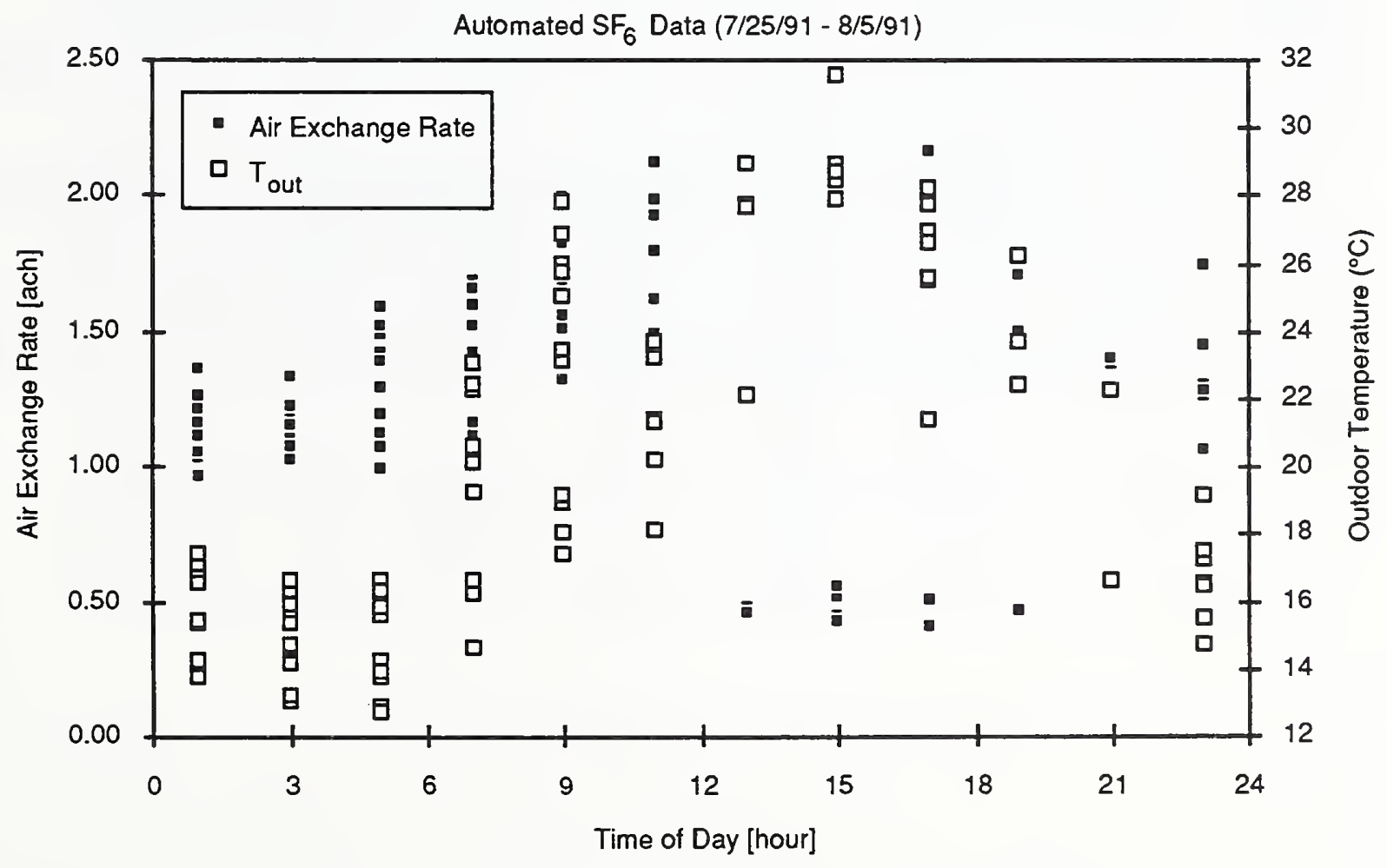

Figure 7: Building air change rates and outdoor temperature versus time of day 


\subsection{Direct Measurement of Ventilation System Airflows}

Direct measurements of system supply and outdoor airflow rates were made during the weeks of 6 August 1991 and 13 January 1992. The results are presented in Tables 1 and 2 respectively. These tables list the date and time the measurements were performed, the measurement location, the measurement instrument used, the design airflow rate capacity at that location in the system, and the percent difference from design (\% DIFF DESIGN = (measured flow - design flow)/design flow) of each measured airflow rate. Measurement locations in individual supply air branches are denoted by their diameters in Table 1. Because the supply fans modulate supply airflow based on cooling demand, the measured supply airflow rates are not expected to equal their design capacities unless the fan is running at full capacity. The minimum outdoor air handler units (AHU-10,11 \& 12) are always run at full capacity; therefore, the differences between the measured and design values are of interest. The airflow rate of AHU-10 was measured six times and always yielded a higher airflow rate than the design value of $2,000 \mathrm{~L} / \mathrm{s}(4,200 \mathrm{cfm})$. Measured values were on the average $20 \%$ higher than the design capacity. AHU-11 was measured three times, and the airflow rates were approximately $20 \%$ lower than design. AHU-12 was measured five times and yielded airflow rates within $+/-7 \%$ of the design capacity. Given the errors associated with these measurements, the agreement between design and measured values is quite good.

The difference between measurements taken at the same location with different instruments was divided by their mean value and is presented in the column labeled "\%DIFF METHOD" in Table 1. Airflow rates measured using the hot wire anemometer and the pitot tube, and the hot wire anemometer and vane anemometer, were generally within $10 \%$ of each other.

In order to evaluate the measurement of the same airflow rate at different locations, measurements of the West air handler system (SFC-5\&6) taken inside the cold supply fan box were compared to the sum of the individual airflow rates measured in the three main supply ducts of the West system. The difference between these measurements divided by the average measured airflow rate ranged from 15 to $30 \%$. 


\begin{tabular}{|c|c|c|c|c|c|c|c|c|}
\hline Date & Time & $\begin{array}{c}\text { Fan } \\
\text { System }\end{array}$ & $\begin{array}{c}\text { Measurement } \\
\text { Location } \\
\end{array}$ & $\begin{array}{c}\text { Measurement } \\
\text { Method }\end{array}$ & $\begin{array}{c}\text { Design } \\
\text { Fiow Rate } \\
\text { [L/s] }\end{array}$ & $\begin{array}{c}\text { Measured } \\
\text { Flow Rate } \\
\text { [L/s] }\end{array}$ & $\begin{array}{l}\% \text { DIFF } \\
\text { DESIGN }\end{array}$ & $\begin{array}{c}\% \text { DiFF } \\
\text { METHOD }\end{array}$ \\
\hline $8 / 6 / 91$ & $9: 30$ & SFC12 & OA Duct & hot wire & 53081 & 46520 & $-12 \%$ & $4 \%$ \\
\hline $8 / 6 / 91$ & $9: 30$ & SFC12 & OA Duct & pitot & 53081 & 48285 & $-9 \%$ & \\
\hline $8 / 6 / 91$ & 11:00 & SFC12 & fan box & hot wire & 53081 & 56397 & $6 \%$ & $3 \%$ \\
\hline $8 / 6 / 91$ & $11: 00$ & SFC12 & fan box & vane & 53081 & 58050 & $9 \%$ & \\
\hline $8 / 6 / 91$ & $11: 00$ & $A H U-10$ & & hot wire & 1982 & 2156 & $9 \%$ & \\
\hline $8 / 6 / 91$ & $14: 30$ & SFC12 & $1.12 \mathrm{~m}$ OD & hot wire & 16416 & 11124 & $-32 \%$ & $16 \%$ \\
\hline $8 / 6 / 91$ & $16: 00$ & SFC12 & $1.12 \mathrm{~m} \mathrm{OD}$ & pitot & 16416 & 13090 & $-20 \%$ & \\
\hline $8 / 6 / 91$ & $15: 00$ & SFC12 & $1.42 \mathrm{~m} \mathrm{OD}$ & hot wire & 29840 & 21887 & $-27 \%$ & $7 \%$ \\
\hline $8 / 6 / 91$ & $16: 00$ & SFC12 & $1.42 \mathrm{~m} \mathrm{OD}$ & pitot & 29840 & 23406 & $-22 \%$ & \\
\hline $8 / 6 / 91$ & $16: 00$ & SFC12 & fan box & hot wire & 53081 & 57605 & $9 \%$ & $7 \%$ \\
\hline $8 / 6 / 91$ & $16: 00$ & SFC12 & $\tan b o x$ & vane & 53081 & 61839 & $16 \%$ & \\
\hline $8 / 6 / 91$ & $15: 00$ & $\mathrm{AHU}-10$ & & pitot & 1982 & 2425 & $22 \%$ & \\
\hline $8 / 6 / 91$ & $16: 40$ & SFC 56 & $0.76 \mathrm{~m} \mathrm{OD}$ & hot wire & 6603 & 6759 & $2 \%$ & $2 \%$ \\
\hline $8 / 6 / 91$ & $16: 40$ & SFC56 & $0.76 \mathrm{~m} \mathrm{OD}$ & pitot & 6603 & 6628 & $0 \%$ & \\
\hline $8 / 6 / 91$ & $16: 30$ & SFC56 & $1.22 \mathrm{~m} \mathrm{OD}$ & hot wire & 20069 & 17130 & $-15 \%$ & $10 \%$ \\
\hline $8 / 6 / 91$ & $16: 30$ & SFC56 & $1.22 \mathrm{~m}$ OD & pitot & 20069 & 15465 & $-23 \%$ & \\
\hline $8 / 6 / 91$ & $16: 50$ & SFC56 & $1.42 \mathrm{~m} \mathrm{OD}$ & hot wire & 27433 & 25880 & $-6 \%$ & $3 \%$ \\
\hline $8 / 6 / 91$ & $16: 50$ & SFC56 & $1.42 \mathrm{~m}$ OD & pitot & 27433 & 25037 & $-9 \%$ & \\
\hline $8 / 6 / 91$ & $16: 40$ & SFC56 & Duct Total & hot wire & 54105 & 49754 & $-8 \%$ & $5 \%$ \\
\hline $8 / 6 / 91$ & $16: 40$ & SFC56 & Duct Total & pitot & 54105 & 47121 & $-13 \%$ & \\
\hline $8 / 6 / 91$ & $17: 00$ & SFC56 & fan box & hot wire & 54105 & 57387 & $6 \%$ & $1 \%$ \\
\hline $8 / 6 / 91$ & $17: 00$ & SFC56 & fan box & vane & 54105 & 58050 & $7 \%$ & \\
\hline $8 / 7 / 91$ & $9: 20$ & SFC12 & $1.12 \mathrm{~m} \mathrm{OD}$ & hot wire & 16416 & 12923 & $-21 \%$ & $26 \%$ \\
\hline $8 / 7 / 91$ & $8: 30$ & SFC12 & $1.12 \mathrm{~m} \mathrm{OD}$ & pitot & 16416 & 9924 & $-40 \%$ & \\
\hline $8 / 7 / 91$ & $9: 30$ & SFC12 & $1.42 \mathrm{~m} \mathrm{OD}$ & hot wire & 29840 & 22004 & $-26 \%$ & $15 \%$ \\
\hline $8 / 7 / 91$ & $8: 40$ & SFC12 & $1.42 \mathrm{~m}$ OD & pitot & 29840 & 18877 & $-37 \%$ & \\
\hline $8 / 7 / 91$ & $8: 30$ & SFC 12 & OA Duct & hot wire & 53081 & 45243 & $-15 \%$ & $18 \%$ \\
\hline $8 / 7 / 91$ & $10: 00$ & SFC12 & OA Duct & pitot & 53081 & 53946 & $2 \%$ & \\
\hline $8 / 7 / 91$ & $10: 15$ & AHU-10 & & hot wire & 1982 & 2375 & $20 \%$ & $4 \%$ \\
\hline $8 / 7 / 91$ & $10: 15$ & $A H U-10$ & & pitot & 1982 & 2473 & $25 \%$ & \\
\hline $8 / 7 / 91$ & $14: 40$ & SFC56 & $0.76 \mathrm{~m}$ OD & hot wire & 6603 & 6575 & $0 \%$ & $0 \%$ \\
\hline $8 / 7 / 91$ & $13: 20$ & SFC56 & $0.76 \mathrm{~m} \mathrm{OD}$ & pitot & 6603 & 6583 & $0 \%$ & \\
\hline $8 / 7 / 91$ & $14: 50$ & SFC56 & $1.22 \mathrm{~m} O D$ & hot wire & 20065 & 15761 & $-21 \%$ & $6 \%$ \\
\hline $8 / 7 / 91$ & $13: 50$ & SFC56 & $1.22 \mathrm{~m} \mathrm{OD}$ & pitot & 20065 & 16703 & $-17 \%$ & \\
\hline $8 / 7 / 91$ & $15: 15$ & SFC56 & $1.42 \mathrm{~m}$ OD & hot wire & 27433 & 22921 & $-16 \%$ & $15 \%$ \\
\hline $8 / 7 / 91$ & $13: 40$ & SFC56 & $1.42 \mathrm{~m} \mathrm{OD}$ & pitot & 27433 & 26544 & $3 \%$ & \\
\hline $8 / 7 / 91$ & $14: 50$ & SFC 56 & Duct Total & hot wire & 54105 & 45257 & $-16 \%$ & $10 \%$ \\
\hline $8 / 7 / 91$ & $13: 40$ & SFC56 & Duct Total & pitot & 54105 & 49831 & $-8 \%$ & \\
\hline $8 / 8 / 91$ & $9: 20$ & SFC12 & $1.12 \mathrm{~m} \mathrm{OD}$ & hot wire & 16416 & 9724 & $-41 \%$ & \\
\hline $8 / 8 / 91$ & $9: 30$ & SFC12 & $1.42 \mathrm{~m} \mathrm{OD}$ & hot wire & 29840 & 19925 & $-33 \%$ & \\
\hline $8 / 8 / 91$ & $9: 25$ & SFC56 & Duct Total & hot wire & 54105 & 48209 & $-11 \%$ & \\
\hline $8 / 8 / 91$ & $10: 35$ & SFC34 & Duct Totai & hot wire & 47856 & 35020 & $-27 \%$ & \\
\hline $8 / 8 / 91$ & $11: 30$ & AHU-12 & & hot wire & 1982 & 1838 & $-7 \%$ & \\
\hline $8 / 8 / 91$ & $12: 00$ & SFC56 & $\operatorname{fan} b o x$ & vane & 54105 & 59813 & $11 \%$ & \\
\hline $8 / 8 / 91$ & $12: 05$ & SFC56 & Duct Total & hot wire & 54105 & 43939 & $-19 \%$ & \\
\hline $8 / 8 / 91$ & $14: 25$ & SFC56 & fan box & vane & 54105 & 56088 & $4 \%$ & \\
\hline $8 / 8 / 91$ & $16: 30$ & SFC56 & fan box & vane & 54105 & 58750 & $9 \%$ & \\
\hline $8 / 8 / 91$ & $16: 40$ & SFC56 & Duct Total & hot wire & 54105 & 44471 & $-18 \%$ & \\
\hline $8 / 8 / 91$ & $14: 30$ & AHU-12 & & pitot & 1982 & 2101 & $6 \%$ & \\
\hline
\end{tabular}

Table 1: Direct airflow measurements - Week 1 


\begin{tabular}{|c|c|c|c|c|c|c|c|}
\hline Date & Time & $\begin{array}{c}\text { Fan } \\
\text { System }\end{array}$ & $\begin{array}{c}\text { Measurement } \\
\text { Location }\end{array}$ & $\begin{array}{l}\text { Measurement } \\
\text { Method }\end{array}$ & $\begin{array}{c}\text { Design } \\
\text { Flow Rate } \\
{[\cup s]}\end{array}$ & $\begin{array}{c}\text { Measured } \\
\text { Flow Rate } \\
\text { [Us] }\end{array}$ & $\begin{array}{l}\% \text { DIFF } \\
\text { DESIGN }\end{array}$ \\
\hline $1 / 14 / 92$ & $10: 50$ & SFC12 & $\operatorname{fan} b o x$ & hot wire & 53081 & 30534 & $-42 \%$ \\
\hline 1/14/92 & $11: 00$ & SFC34 & fan box & hot wire & 47856 & 35041 & $-27 \%$ \\
\hline $1 / 14 / 92$ & $10: 40$ & SFC56 & fan box & hot wire & 54105 & 28847 & $-47 \%$ \\
\hline $1 / 14 / 92$ & $13: 40$ & SFC56 & fan box & hot wire & 54105 & 29605 & $-45 \%$ \\
\hline 1/14/92 & $16: 10$ & SFC12 & fan box & hot wire & 53081 & 28499 & $-46 \%$ \\
\hline $1 / 14 / 92$ & $16: 00$ & SFC34 & fan box & hot wire & 47856 & 35544 & $-26 \%$ \\
\hline $1 / 14 / 92$ & $16: 20$ & SFC56 & fan box & hot wire & 54105 & 26386 & $-51 \%$ \\
\hline 1/15/92 & $9: 25$ & SFC 12 & fan box & hot wire & 53081 & 57157 & $8 \%$ \\
\hline $1 / 15 / 92$ & $9: 40$ & SFC34 & fan box & hot wire & 47856 & 38591 & $-19 \%$ \\
\hline $1 / 15 / 92$ & $9: 15$ & SFC56 & fan box & hot wire & 54105 & 51522 & $-5 \%$ \\
\hline $1 / 15 / 92$ & $15: 00$ & $\mathrm{SFC} 12$ & fan box & hot wire & 53081 & 28356 & $-47 \%$ \\
\hline $1 / 15 / 92$ & $15: 50$ & SFC34 & fan box & hot wire & 47856 & 22849 & $-52 \%$ \\
\hline $1 / 15 / 92$ & $16: 10$ & SFC56 & fan box & hot wire & 54105 & 24948 & $-54 \%$ \\
\hline $1 / 16 / 92$ & $8: 15$ & $\mathrm{SFC} 12$ & $\tan b o x$ & hot wire & 53081 & 54329 & $2 \%$ \\
\hline $1 / 16 / 92$ & $8: 30$ & SFC 34 & fan box & hot wire & 47856 & 37538 & $-22 \%$ \\
\hline $1 / 16 / 92$ & $8: 00$ & SFC56 & fan box & hot wire & 54105 & 40171 & $-26 \%$ \\
\hline $1 / 16 / 92$ & $11: 50$ & SFC 12 & fan box & hot wire & 53081 & 56048 & $6 \%$ \\
\hline $1 / 16 / 92$ & $12: 00$ & SFC34 & fan box & hot wire & 47856 & 42268 & $-12 \%$ \\
\hline $1 / 16 / 92$ & $11: 40$ & SFC56 & fan box & hot wire & 54105 & 56058 & $4 \%$ \\
\hline $1 / 16 / 92$ & $14: 15$ & SFC12 & $\tan b o x$ & hot wire & 53081 & 55201 & $4 \%$ \\
\hline $1 / 16 / 92$ & $14: 30$ & SFC34 & fan box & hot wire & 47856 & 38847 & $-19 \%$ \\
\hline $1 / 16 / 92$ & $14: 00$ & SFC56 & fan box & hot wire & 54105 & 55965 & $3 \%$ \\
\hline $1 / 15 / 92$ & $13: 50$ & AHU-10 & & hot wire & 1982 & 2441 & $23 \%$ \\
\hline $1 / 16 / 92$ & $9: 30$ & $A H U-10$ & & hot wire & 1982 & 2560 & $29 \%$ \\
\hline $1 / 15 / 92$ & $11: 30$ & $A H U-11$ & & hot wire & 1982 & 1556 & $-22 \%$ \\
\hline $1 / 16 / 92$ & $8: 40$ & AHU-11 & & hot wire & 1982 & 1589 & $-20 \%$ \\
\hline $1 / 16 / 92$ & $11: 40$ & AHU-11 & & hot wire & 1982 & 1644 & $-17 \%$ \\
\hline $1 / 15 / 92$ & $14: 15$ & $A H U-12$ & & hot wire & 1982 & 1865 & $-6 \%$ \\
\hline 1/16/92 & 9:10 & AHU-12 & & & 1982 & 1864 & $-6 \%$ \\
\hline $1 / 16 / 92$ & $11: 30$ & AHU-12 & & hot wire & 1982 & 1838 & $-7 \%$ \\
\hline
\end{tabular}

Table 2: Direct airflow measurements - Week 2 


\subsection{Percent Outdoor Air Intake}

\subsubsection{Percent Outdoor Air: $\mathrm{SF}_{6}$ and $\mathrm{CO}_{2}$ Automated}

Percent outdoor air intake rates, based on data collected by the $\mathrm{SF}_{6}$ tracer gas system during the previous study, were determined for the Center air handling system for the period of September 1987 to July 1989 and are presented in Figure 8 along with the new measurements. An average maximum outdoor air intake rate of $83 \%$ occurred when outdoor temperatures were between 15 and $25^{\circ} \mathrm{C}\left(59\right.$ and $\left.77^{\circ} \mathrm{F}\right)$, and a minimum of about $8 \%$ occurred when the outdoor temperature was above about $25^{\circ} \mathrm{C}$ $\left(77^{\circ} \mathrm{F}\right)$. The percent outdoor air intake was modulated when the outdoor temperature was below $15^{\circ} \mathrm{C}\left(59^{\circ} \mathrm{F}\right)$. The data in this graph are very similar to the sketch shown in Figure 4, which indicates the outdoor air intake control was operating as intended.

For this study, percent outdoor air intake was continuously monitored using both the automated $\mathrm{SF}_{6}$ tracer gas system and the automated $\mathrm{CO}_{2}$ system simultaneously. Figure 8 shows percent outdoor air intake rates for all three main fan systems as determined by the automated $\mathrm{SF}_{6}$ system. Figure 9 shows percent outdoor air intake measured with the automated $\mathrm{CO}_{2}$ system. Note that the temperature scale for the Center System in Figure 8 is different than the scales used in the other graphs. All three fan systems have approximately the same minimum outdoor air intake rate of about $10 \%$ compared to a design value of $4 \%$. The average maximum rates of the Center, East, and West systems (SFC-1\&2, SFC-3\&4 and SFC-5\&6) are 82\%, 60\% and $74 \%$ respectively based on the $\mathrm{SF}_{6}$ data. 

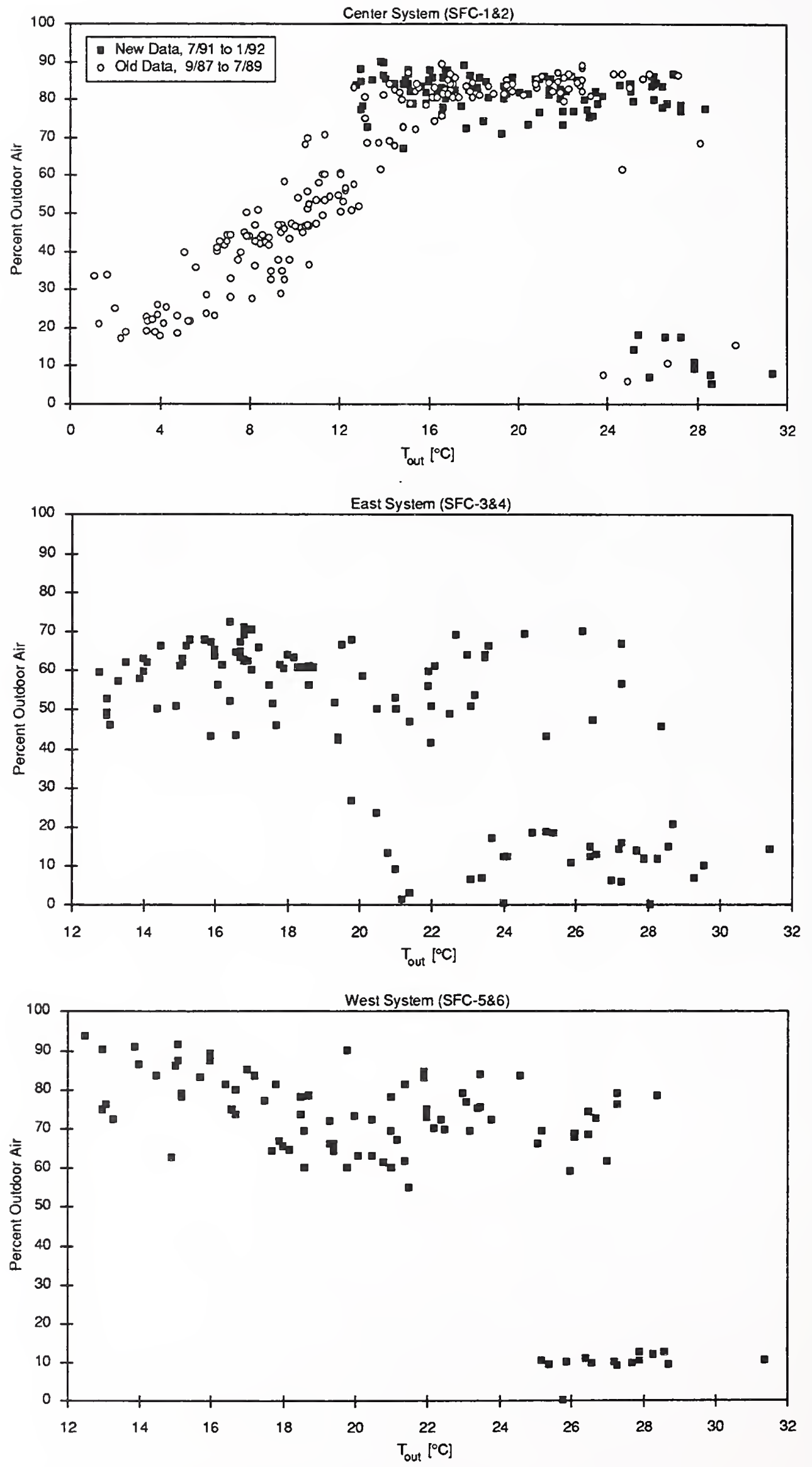

Figure 8: Percent outdoor air intake ( $\mathrm{SF}_{6}$ automated)

18 

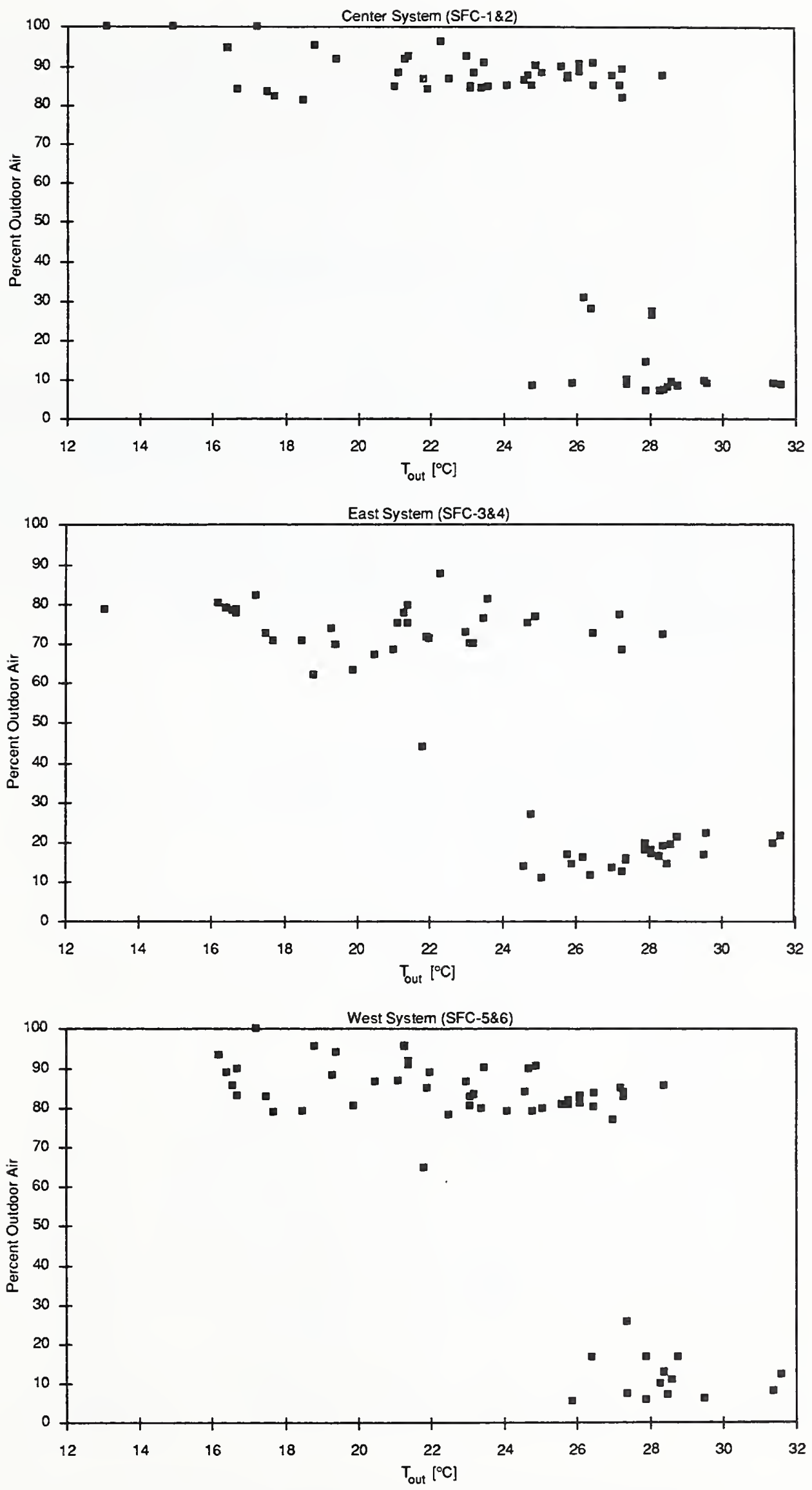

Figure 9: Percent outdoor air intake $\left(\mathrm{CO}_{2}\right.$ automated $)$ 


\subsubsection{Percent Outdoor Air: $\mathrm{CO}_{2}$ Detector Tubes}

The results of the percent outdoor air intake determinations based on $\mathrm{CO}_{2}$ detector tube measurements are presented in Table 3. Table 3 shows the individual detector tube readings divided by the number of pump strokes used to take the sample. The percent outdoor air based on the readings obtained by each individual are shown, along with the mean and standard deviation of these three readings. The averages of the concentration readings taken by the three people were also used to calculate the percent outdoor air intake rates given in bold in Table 3. The values to the right of the bold values are the measurement errors, given in percent outdoor air. The determinations on 8 August 1991 and 15 January 1992 were all done by a single person and error estimates are shown for each value of percent outdoor air. These error estimates are based on an uncertainty in the $\mathrm{CO}_{2}$ concentrations of $33 \mathrm{ppm}$.

The percent outdoor air calculations based on one individual's readings are quite variable and subject to significant errors. These inaccuracies are due to the low resolution of the detector tubes, the difficulty in reading the tubes, and calibration errors. In some cases the single-person results were quite unreasonable, i.e., less than $0 \%$ or greater than $100 \%$. 


\begin{tabular}{|c|c|c|c|c|c|c|c|}
\hline \multirow{2}{*}{ Date } & \multirow{2}{*}{ Time } & \multirow{2}{*}{ System } & \multicolumn{3}{|c|}{$\mathrm{CO}_{2}$ Concentrations } & \multirow{2}{*}{$\% O A$} & \multirow{2}{*}{ Person } \\
\hline & & & Supply & Return & Outdoor & & \\
\hline \multirow[t]{5}{*}{$8 / 6 / 91$} & \multirow[t]{5}{*}{$10: 10$} & \multirow[t]{4}{*}{ SFC12 } & \multirow{4}{*}{$\begin{array}{l}467 \\
467 \\
317\end{array}$} & 533 & \multirow{4}{*}{$\begin{array}{l}417 \\
417 \\
300\end{array}$} & $57 \%$ & 1 \\
\hline & & & & \multirow{3}{*}{$\begin{array}{l}567 \\
433\end{array}$} & & $67 \%$ & 2 \\
\hline & & & & & & $87 \%$ & 3 \\
\hline & & & & & & $\begin{array}{l}70 \% \\
13 \% \\
\end{array}$ & $\begin{array}{l}<- \text { Avg } \\
<- \text { Std }\end{array}$ \\
\hline & & Avg $\cdots>$ & 417 & 511 & 378 & $71 \%$ & $\pm 43 \%$ \\
\hline \multirow[t]{5}{*}{$8 / 6 / 91$} & \multirow[t]{5}{*}{$10: 40$} & \multirow[t]{5}{*}{ SFC12 } & 467 & 533 & 417 & $57 \%$ & 1 \\
\hline & & & 467 & 567 & 433 & $75 \%$ & 2 \\
\hline & & & \multirow[t]{2}{*}{433} & \multirow[t]{2}{*}{500} & \multirow[t]{2}{*}{400} & $67 \%$ & 3 \\
\hline & & & & & & $\begin{array}{c}66 \% \\
7 \%\end{array}$ & $\begin{array}{l}<- \text { Avg } \\
<- \text { Std }\end{array}$ \\
\hline & & & 456 & 533 & 417 & $67 \%$ & $\pm 48 \%$ \\
\hline \multirow[t]{5}{*}{$8 / 7 / 91$} & \multirow[t]{5}{*}{$8: 30$} & \multirow[t]{4}{*}{ SFC12 } & & 500 & 417 & $100 \%$ & 1 \\
\hline & & & 417 & 500 & 433 & $125 \%$ & 2 \\
\hline & & & & 467 & 400 & $125 \%$ & 3 \\
\hline & & & & & & $\begin{array}{c}117 \% \\
12 \% \\
\end{array}$ & $\begin{array}{l}<- \text { Avg } \\
<- \text { Std }\end{array}$ \\
\hline & & Avg $->>$ & 406 & 489 & 417 & $115 \%$ & $\pm 100 \%$ \\
\hline $8 / 7 / 91$ & 10:35 & SFC12 & 467 & 500 & 467 & $100 \%$ & 1 \\
\hline & & & 467 & 500 & 500 & ERR & 2 \\
\hline & & & 433 & 500 & 433 & $100 \%$ & 3 \\
\hline & & & & & & $\begin{array}{l}\text { ERR } \\
\text { ERR }\end{array}$ & $\begin{array}{l}<- \text { Avg } \\
<- \text { Std }\end{array}$ \\
\hline & & Avg--> & 456 & 500 & 467 & $133 \%$ & $\pm 237 \%$ \\
\hline $8 / 7 / 91$ & $13: 30$ & SFC56 & 400 & 500 & 433 & $150 \%$ & 1 \\
\hline & & & 400 & 500 & 467 & $300 \%$ & 2 \\
\hline & & & 400 & 500 & 400 & $100 \%$ & 3 \\
\hline & & & & & & $\begin{array}{c}183 \% \\
85 \%\end{array}$ & $\begin{array}{l}<- \text { Avg } \\
<- \text { Std }\end{array}$ \\
\hline & & Avg $\cdot>$ & 400 & 500 & 433 & $150 \%$ & $\pm 126 \%$ \\
\hline $8 / 7 / 91$ & $15: 30$ & SFC56 & 667 & 767 & 467 & $33 \%$ & 1 \\
\hline & & & 733 & 700 & 433 & $-12 \%$ & 2 \\
\hline & & & 667 & 700 & 433 & $12 \%$ & 3 \\
\hline & & & & & & $\begin{array}{l}11 \% \\
19 \%\end{array}$ & $\begin{array}{l}<- \text { Avg } \\
<- \text { Std }\end{array}$ \\
\hline & & Avg - > & 689 & 722 & 444 & $12 \%$ & $\pm 17 \%$ \\
\hline $8 / 8 / 91$ & $11: 00$ & SFC56 & 667 & 600 & 417 & $-36 \%$ & $\pm 27 \%$ \\
\hline $8 / 8 / 91$ & $11: 30$ & SFC56 & 567 & 700 & 467 & $57 \%$ & $\pm 23 \%$ \\
\hline $8 / 8 / 91$ & $17: 25$ & SFC56 & 550 & 750 & 525 & $89 \%$ & $\pm 28 \%$ \\
\hline $8 / 8 / 91$ & 18:05 & SFC56 & 550 & 600 & 500 & $50 \%$ & $\pm 53 \%$ \\
\hline $1 / 15 / 92$ & $11: 00$ & SFC12 & 900 & 1067 & 475 & $28 \%$ & $\pm 8 \%$ \\
\hline $1 / 15 / 92$ & & SFC34 & 967 & 1067 & 475 & $17 \%$ & $\pm 8 \%$ \\
\hline $1 / 15 / 92$ & & SFC56 & 1000 & 1267 & 475 & $34 \%$ & $\pm 6 \%$ \\
\hline $1 / 15 / 92$ & $14: 00$ & SFC12 & 933 & 1125 & 454 & $29 \%$ & $\pm 7 \%$ \\
\hline $1 / 15 / 92$ & & SFC34 & 983 & 1050 & 454 & $11 \%$ & $\pm 8 \%$ \\
\hline $1 / 15 / 92$ & & SFC56 & 1050 & 1483 & 454 & $42 \%$ & $\pm 5 \%$ \\
\hline
\end{tabular}

Table 3: Percent outdoor air by $\mathrm{CO}_{2}$ detector tubes 


\subsubsection{Percent Outdoor Air: Direct Airflow Measurement}

Percent outdoor air intake rates were determined under both minimum and maximum percent outdoor air intake conditions during the first week of direct airflow measurements and under minimum outdoor air intake conditions during the second week. These values of percent outdoor air intake were determined by dividing the airflow rate measured in the outdoor air intake ducts by the supply airflow rate, with both values being obtained by duct traverses. Table 4 lists the results of these determinations along with the mixed-air damper status for the fan system being measured as obtained from the HVAC control system. Very few measurements were made with the mixed-air dampers open because of difficulties in accessing some of the duct work and due to the modulation of damper positions and fan vane settings during traverses.

\begin{tabular}{|c|c|c|c|c|}
\hline Date & Time & System & $\begin{array}{c}\% \text { Outdoor Air } \\
\text { by Direct Flow } \\
\text { Method }\end{array}$ & $\begin{array}{c}\text { Mixed-air } \\
\text { Damper } \\
\text { Status } \\
{[\% \text { open] }}\end{array}$ \\
\hline $8 / 6 / 91$ & $10: 10$ & SFC-1\&2 & $87 \%$ & $100 \%$ \\
& $10: 40$ & SFC-1\&2 & $87 \%$ & $100 \%$ \\
& $16: 40$ & SFC-5\&6 & $3 \%$ & $0 \%$ \\
\hline $8 / 7 / 91$ & $15: 00$ & SFC-5\&6 & $4 \%$ & $0 \%$ \\
\hline $8 / 8 / 91$ & $11: 30$ & SFC-5\&6 & $3 \%$ & $0 \%$ \\
& $16: 30$ & SFC-5\&6 & $4 \%$ & $0 \%$ \\
\hline $1 / 15 / 92$ & $9: 25$ & SFC-1\&2 & $4 \%$ & $5 \%$ \\
& $9: 40$ & SFC-3\&4 & $4 \%$ & $0 \%$ \\
& $9: 15$ & SFC-5\&6 & $4 \%$ & $0 \%$ \\
\hline $1 / 16 / 92$ & $8: 00$ & SFC-1\&2 & $5 \%$ & $4 \%$ \\
& $8: 15$ & SFC-3\&4 & $4 \%$ & $0 \%$ \\
& $8: 30$ & SFC-5\&6 & $5 \%$ & $0 \%$ \\
\hline $1 / 16 / 92$ & $11: 50$ & SFC-1\&2 & $5 \%$ & $4 \%$ \\
& $12: 00$ & SFC-3\&4 & $4 \%$ & $0 \%$ \\
& $11: 40$ & SFC-5\&6 & $3 \%$ & $0 \%$ \\
\hline $1 / 16 / 92$ & $14: 15$ & SFC-1\&2 & $4 \%$ & $4 \%$ \\
& $14: 25$ & SFC-3\&4 & $4 \%$ & $0 \%$ \\
& $14: 05$ & SFC-5\&6 & $4 \%$ & $0 \%$ \\
\hline
\end{tabular}

Table 4: Percent outdoor air intake measurements by the direct flow method 


\subsection{Ventilation Rate Per Person}

\subsubsection{Ventilation Rate Per Person: $\mathrm{SF}_{6}$ Automated}

Table 5 shows the whole building air change rate determined by the tracer gas decay method and the ventilation rate per person based on the measured air change rate, 2000 building occupants, and a building volume of $114,000 \mathrm{~m}^{3}\left(4,030,000 \mathrm{ft}^{3}\right)$. The measurement error associated with the ventilation rate as determined by the tracer gas decay method is approximately $10 \%$ of the indicated values. The values obtained during minimum outdoor air intake were approximately $8 \mathrm{~L} / \mathrm{s}(16 \mathrm{cfm})$ per person which is higher than the recommended minimum outdoor air intake given in ASHRAE Standard 62-1981 (2.5 L/s per person, $5 \mathrm{cfm}$ per person) and slightly lower than the value in ASHRAE Standard 62-1989 (10 L/s per person, $20 \mathrm{cfm}$ per person). These values include both intentional outdoor air intake through the ventilation system and unintentional air leakage through the building envelope.

\begin{tabular}{|c|r||c|c|c|}
\hline \multirow{2}{*}{ Date } & \multicolumn{1}{|c||}{$H r$} & \multicolumn{3}{c|}{$\mathrm{SF}_{6}$ Decay } \\
\cline { 3 - 5 } & & ach & \multicolumn{2}{|c|}{ per person } \\
\cline { 3 - 5 } & & & {$[\mathrm{L}$ s] } & {$[\mathrm{cfm}]$} \\
\hline $7 / 26 / 91$ & 9 & 1.7 & 27 & 57 \\
$7 / 29 / 91$ & 9 & 1.8 & 29 & 62 \\
$7 / 30 / 91$ & 9 & 1.8 & 29 & 61 \\
$7 / 31 / 91$ & 9 & 2.0 & 32 & 67 \\
$7 / 31 / 91$ & 15 & 0.5 & 8 & 16 \\
$8 / 01 / 91$ & 9 & 1.9 & 30 & 63 \\
$8 / 12 / 91$ & 9 & 1.7 & 27 & 57 \\
$8 / 12 / 91$ & 17 & 0.5 & 8 & 17 \\
$8 / 13 / 91$ & 9 & 1.9 & 30 & 64 \\
$8 / 14 / 91$ & 9 & 1.8 & 28 & 59 \\
$8 / 14 / 91$ & 16 & 0.6 & 9 & 19 \\
$8 / 15 / 91$ & 9 & 2.1 & 33 & 71 \\
$8 / 15 / 91$ & 15 & 0.6 & 9 & 19 \\
$8 / 16 / 91$ & 10 & 1.6 & 25 & 52 \\
$8 / 19 / 91$ & 9 & 1.9 & 31 & 65 \\
$8 / 19 / 91$ & 15 & 0.6 & 9 & 19 \\
$8 / 20 / 91$ & 9 & 1.8 & 29 & 61 \\
$8 / 20 / 91$ & 15 & 0.6 & 9 & 18 \\
$8 / 21 / 91$ & 8 & 1.6 & 26 & 54 \\
$8 / 21 / 91$ & 15 & 0.6 & 9 & 20 \\
$1 / 15 / 92$ & 11 & 0.4 & 7 & 15 \\
$1 / 16 / 92$ & 11 & 0.4 & 7 & 14 \\
\hline
\end{tabular}

Table 5: Ventilation rates per person $\left(\mathrm{SF}_{6}\right.$ automated $)$ 


\subsubsection{Ventilation Rate Per Person: Peak $\mathrm{CO}_{2}$ Automated}

Building ventilation rate estimates based on equilibrium analysis were determined using the peak values of the average building $\mathrm{CO}_{2}$ concentration. These concentrations were measured in the return ducts of the main air handlers using the automated $\mathrm{CO}_{2}$ system. Table 6 shows the calculated ventilation rate per person based on Equation 2, the building air change rate corresponding to this ventilation rate, and the measurement error in the calculated ventilation rate. Under minimum percent outdoor air intake, the peak $\mathrm{CO}_{2}$ method yielded a ventilation rate of about $15 \mathrm{~L} / \mathrm{s}(30$ $\mathrm{cfm})$ per person and about $50 \mathrm{~L} / \mathrm{s}(100 \mathrm{cfm})$ per person under maximum percent outdoor air intake conditions.

The measurement errors shown in Table 6 are based on the accuracy of the infrared $\mathrm{CO}_{2}$ monitor utilized by the automated system and the propagation of error in calculating $Q_{p}$ using Equation 2. The errors do not include other sources of error such as uncertainties in the number of building occupants, changes in the number of building occupants, variations in the ventilation rate, non-constant outdoor $\mathrm{CO}_{2}$ concentrations, nonuniformities in the $\mathrm{CO}_{2}$ concentrations within the building, and the indoor $\mathrm{CO}_{2}$ concentration not being at equilibrium.

\begin{tabular}{|c|c|c|c|c|c|}
\hline \multirow{3}{*}{ Date } & \multirow{3}{*}{$\mathrm{Hr}$} & \multicolumn{4}{|c|}{ Peak $\mathrm{CO}_{2}$ Automated } \\
\hline & & \multicolumn{2}{|c|}{ per person } & \multirow{2}{*}{ ach } & \multirow{2}{*}{$\begin{array}{l}\% \\
\text { error }\end{array}$} \\
\hline & & {$[\mathrm{L} / \mathrm{s}]$} & {$[\mathrm{cfm}]$} & & \\
\hline $7 / 26 / 91$ & 9 & 50 & 106 & 3.2 & 5.6 \\
\hline $7 / 26 / 91$ & 14 & 41 & 87 & 2.6 & 3.1 \\
\hline $7 / 29 / 91$ & 9 & 45 & 96 & 2.9 & 4.1 \\
\hline $7 / 29 / 91$ & 15 & 15 & 33 & 1.0 & 0.2 \\
\hline $7 / 30 / 91$ & 9 & 49 & 103 & 3.1 & 5.1 \\
\hline $7 / 30 / 91$ & 16 & 21 & 44 & 1.3 & 0.4 \\
\hline $7 / 31 / 91$ & 9 & 52 & 111 & 3.3 & 6.4 \\
\hline $7 / 31 / 91$ & 15 & 18 & 38 & 1.1 & 0.3 \\
\hline $8 / 01 / 91$ & 9 & 54 & 115 & 3.4 & 7.0 \\
\hline $8 / 12 / 91$ & 9 & 43 & 90 & 2.7 & 3.4 \\
\hline $8 / 12 / 91$ & 17 & 37 & 78 & 2.3 & 2.2 \\
\hline $8 / 13 / 91$ & 9 & 45 & 95 & 2.8 & 4.0 \\
\hline $8 / 13 / 91$ & 14 & 40 & 84 & 2.5 & 2.8 \\
\hline $8 / 14 / 91$ & 9 & 45 & 95 & 2.8 & 4.0 \\
\hline $8 / 14 / 91$ & 16 & 20 & 41 & 1.2 & 0.3 \\
\hline $8 / 15 / 91$ & 9 & 47 & 100 & 3.0 & 4.6 \\
\hline $8 / 15 / 91$ & 15 & 15 & 31 & 0.9 & 0.1 \\
\hline $8 / 16 / 91$ & 10 & 45 & 95 & 2.8 & 4.1 \\
\hline 8/19/91 & 9 & 43 & 92 & 2.7 & 3.6 \\
\hline $8 / 19 / 91$ & 15 & 20 & 43 & 1.3 & 0.4 \\
\hline $8 / 20 / 91$ & 9 & 52 & 109 & 3.3 & 6.1 \\
\hline $8 / 20 / 91$ & 15 & 17 & 37 & 1.1 & 0.2 \\
\hline $8 / 21 / 91$ & 8 & 49 & 103 & 3.1 & 5.2 \\
\hline $8 / 21 / 91$ & 15 & 18 & 37 & 1.1 & 0.2 \\
\hline $8 / 22 / 91$ & 9 & 45 & 95 & 2.8 & 4.0 \\
\hline $8 / 22 / 91$ & 15 & 16 & 34 & 1.0 & 0.2 \\
\hline 1/15/92 & 11 & 14 & 30 & 0.9 & 0.1 \\
\hline $1 / 16 / 92$ & 11 & 13 & 27 & 0.8 & 0.1 \\
\hline
\end{tabular}

Table 6: Ventilation rates per person (Peak $\mathrm{CO}_{2}$ automated) 


\subsubsection{Ventilation Rate Per Person: Peak $\mathrm{CO}_{2}$ Detector Tubes}

Peak $\mathrm{CO}_{2}$ was measured with detector tubes on 15 and 16 January 1992.

Measurements were performed in the 3 main return air ducts on the fifteenth and in several locations in the office space on the sixteenth. The calculated ventilation rates per person under minimum outdoor air intake conditions were approximately $9 \mathrm{~L} / \mathrm{s}(18$ $\mathrm{cfm}$ ) per person on both days.

\subsubsection{Ventilation Rate Per Person: Peak $\mathrm{CO}_{2}$ Air Sample Bags}

Peak $\mathrm{CO}_{2}$ was determined in the office space on 16 January 1992 using air sample bags and the infrared $\mathrm{CO}_{2}$ analyzer of the automated system. The interior sample concentrations ranged from 450 to $1200 \mathrm{ppm}$, and the outdoor concentration was approximately $500 \mathrm{ppm}$. The ventilation rate per person based on the average of these interior measurements was approximately $16 \mathrm{~L} / \mathrm{s}(32 \mathrm{cfm})$ per person. For comparison, a value of $13 \mathrm{~L} / \mathrm{s}(26 \mathrm{cfm})$ per person was obtained using the automated $\mathrm{CO}_{2}$ system to measure the return air concentrations at the main air handlers.

\subsubsection{Ventilation Rate Per Person: Multiplicative Method}

Table 7 displays the results of the determinations of per person ventilation rate based on the multiplicative procedure during the week of 13 January 1992. Of particular interest are the four sets of measurements performed under minimum outdoor air intake conditions. Excellent agreement was obtained between per person ventilation rates as determined using the percent outdoor air intake rates based on the automated $\mathrm{SF}_{6}$ and automated $\mathrm{CO}_{2}$ systems and the results obtained based on $\mathrm{SF}_{6}$ decay. The ventilation rates per person obtained by the direct measurement of the minimum outdoor air intake fan airflow rates were approximately one half the rates obtained using the multiplicative methods based on the automated $\mathrm{SF}_{6}$ and $\mathrm{CO}_{2}$ systems. Results based on the $\mathrm{CO}_{2}$ detector tubes were inconsistent with the results of the other methods.

\begin{tabular}{|c|r|r||c|c|c|c||c|}
\hline \multicolumn{2}{|c||}{} & \multicolumn{5}{c||}{ Ventilation Rates [U/s per person] } \\
\hline Date & Time & \%OA & $\begin{array}{c}\mathrm{CO}_{2} \\
\text { Auto }\end{array}$ & $\begin{array}{c}\mathrm{CO}_{2} \\
\text { Tube }\end{array}$ & $\begin{array}{c}\mathrm{SF}_{6} \\
\text { Auto }\end{array}$ & $\begin{array}{c}\text { Direct } \\
\text { Flow }\end{array}$ & $\begin{array}{c}\mathrm{SF}_{6} \\
\text { Decay }\end{array}$ \\
\hline \hline $1 / 14 / 92$ & 16 & $\max$ & 34 & -- & 30 & -- & - \\
\hline $1 / 15 / 92$ & 9 & $\min$ & 6 & 20 & 7 & 3 & 7 \\
\hline $1 / 15 / 92$ & 16 & $\max$ & 28 & 10 & 25 & -- & 16 \\
\hline $1 / 16 / 92$ & 8 & $\min$ & 7 & -- & 6 & 3 & 7 \\
\hline $1 / 16 / 92$ & 12 & $\min$ & 7 & -- & 5 & 3 & 7 \\
\hline $1 / 16 / 92$ & 14 & $\min$ & 6 & -- & 5 & 3 & 7 \\
\hline
\end{tabular}

Table 7: Ventilation rate per person (multiplicative method) 


\section{5 $\mathrm{CO}_{2}$ Build-up Analysis}

The build-up analysis was performed with the data collected on 15 and 16 January under minimum outdoor air intake conditions between 9:00 and 11:00 a.m. The results are presented in Table 8. A plot of the data collected on 15 January along with the nonlinear curve fit to the data are shown in Figure 10. Table 8 lists the air change rate and the per person $\mathrm{CO}_{2}$ generation rate based on the curve fit and the whole building air change rate determined by $\mathrm{SF}_{6}$ decay.

\begin{tabular}{|c|c|c|c|c|}
\hline \multirow{2}{*}{ Date } & \multirow{2}{*}{ Time } & \multicolumn{2}{|c|}{ Regression Results } & \multirow{2}{*}{$\begin{array}{c}\text { SF }_{6} \text { Decay } \\
\text { [ach] }\end{array}$} \\
\cline { 3 - 4 } & & $\begin{array}{c}\mathrm{I} \\
\text { [ach] }\end{array}$ & {$\left[\mathrm{m}^{3} / \mathrm{s}\right.$ per person] } & [ach] \\
\hline $1 / 15 / 92$ & $9: 00-11: 00$ & 0.59 & $4.06 \times 10^{-6}$ & 0.44 \\
\hline $1 / 16 / 92$ & $9: 00-11: 00$ & 0.40 & $3.48 \times 10^{-6}$ & 0.43 \\
\hline
\end{tabular}

Table 8: $\mathrm{CO}_{2}$ build-up results

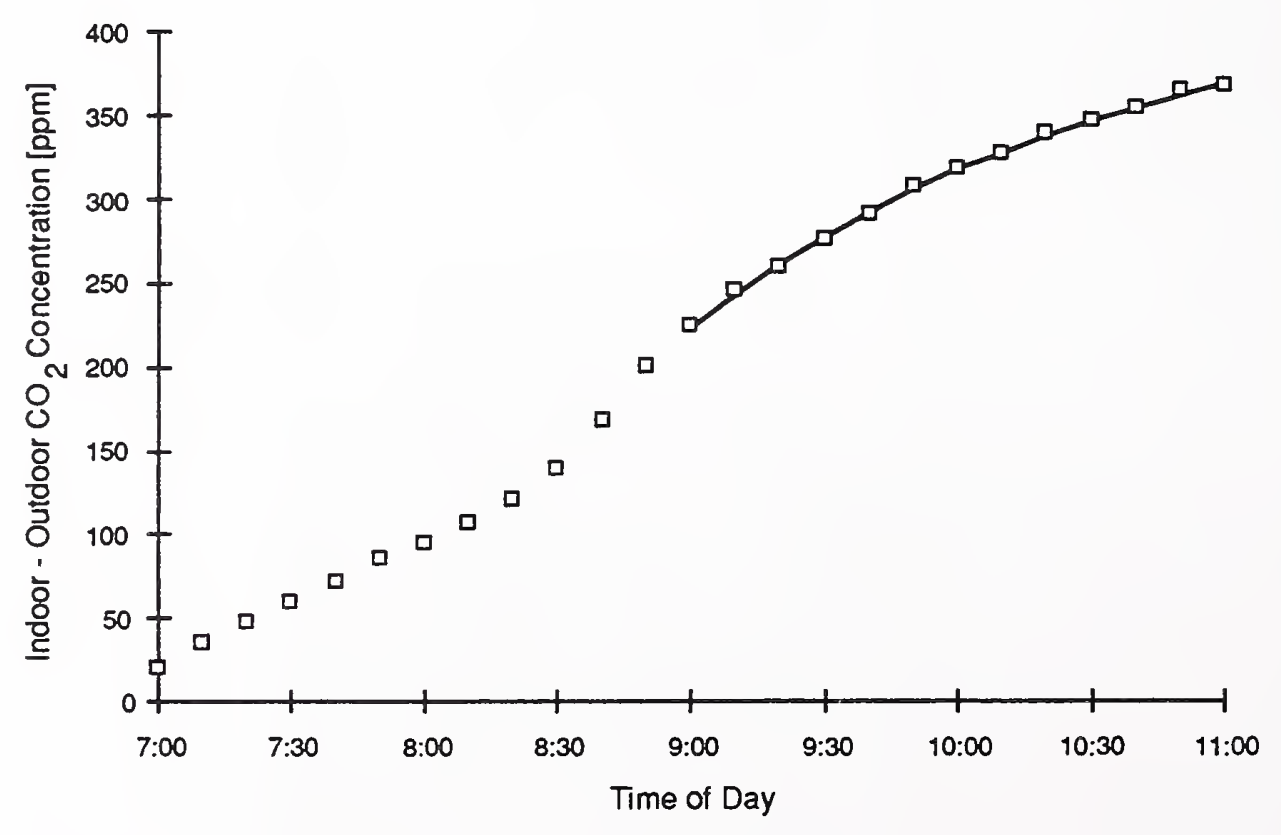

Figure 10: Non-linear curve fit of $\mathrm{CO}_{2}$ build-up data (1/15/92) 


\subsection{Measurement Results}

\subsubsection{Direct Measurement of Ventilation System Airflows}

In making direct measurements of ventilation system airflow rates using duct traverses, the impact of practical considerations on the use of these techniques was noted. As expected, the physical configuration of the HVAC system and the manner in which it is operated can limit which airflows can be measured, when they can be measured and the accuracy of the measurements. None of the airflow rate measurement locations were consistent with handbook recommendations for pitot tube or hot-wire traverses [ACGIH 1988 and ASHRAE 1989b]. All of the traverse locations represented a compromise with recommended practice, but the results obtained appeared to be consistent and reasonable. In some cases, ducts of interest were entirely inaccessible. Along with these physical constraints, there are also time constraints associated with these airflow measurements. Throughout the course of a day, changes in system demands affect system airflow rates. This factor was particularly evident during the first week of measurements when the weather was quite warm, i.e., close to the economizer shut-off set-point $T_{\text {off }}$. Under these conditions, the building operated with the mixed-air dampers wide open until the outdoor air temperature increased above $\mathrm{T}_{\text {off }}$, at which point these dampers shut and the intake was reduced to its minimum value. Several duct traverses were interrupted by this sudden change in airflow rate. Such system effects can sometimes be anticipated, but this requires an understanding of how the system is intended to work and, more importantly, how the system is actually working.

The measurements of ventilation system airflow rates using pitot tube, hot wire anemometer and vane anemometer duct traverses were generally consistent with each other even though the duct configurations were not consistent with standard recommendations. Measurements of the same airflow rate using these different devices were generally within $10 \%$ of each other.

\subsubsection{Percent Outdoor Air Intake Rate}

The percent outdoor air intake in the building air handlers was measured using four techniques: tracer gas balance using $\mathrm{SF}_{6}, \mathrm{CO}_{2}$ balance using the automated $\mathrm{CO}_{2}$ system, $\mathrm{CO}_{2}$ balance using detector tubes, and direct measurement of the system airflow rates. Table 9 compares the results of the measurements based on $\mathrm{SF}_{6}$ and $\mathrm{CO}_{2}$ balances. Percent outdoor air intake rates based on the automated $\mathrm{SF}_{6}$ and $\mathrm{CO}_{2}$ test results are generally in good agreement with each other as seen in Figures 8 and 9. All three fan systems have approximately the same minimum outdoor air intake rate of about $10 \%$ compared to the design value of $4 \%$. As seen in Table 9 , the determination of percent outdoor air intake based on detector tube readings were often quite inaccurate, particularly at low values of percent outdoor air intake. 


\begin{tabular}{|c|c|c|c|c|c|c|}
\hline \multirow[b]{2}{*}{ Date } & \multirow[b]{2}{*}{ Time } & \multirow[b]{2}{*}{ System } & \multicolumn{4}{|c|}{ Percent Outdoor Air } \\
\hline & & & $\begin{array}{c}\mathrm{CO}_{2} \\
\text { Tubes } \\
\text { (1 person) }\end{array}$ & $\begin{array}{c}\mathrm{CO}_{2} \\
\text { Tubes } \\
(3 \text { person) } \\
\end{array}$ & $\begin{array}{l}\mathrm{CO}_{2} \\
\text { Auto }\end{array}$ & $\begin{array}{l}\mathrm{SF}_{6} \\
\text { Auto }\end{array}$ \\
\hline \multirow[t]{2}{*}{$8 / 6 / 91$} & 10:10 & SFC-1\&2 & $57 \%$ & $71 \%$ & $87 \%$ & \\
\hline & $10: 40$ & SFC-1\&2 & $57 \%$ & $67 \%$ & $82 \%$ & \\
\hline \multirow[t]{4}{*}{$8 / 7 / 91$} & $8: 30$ & SFC-1\&2 & $100 \%$ & $115 \%$ & $90 \%$ & \\
\hline & 10:35 & SFC-1\&2 & $100 \%$ & $133 \%$ & $90 \%$ & \\
\hline & 13:30 & SFC-5\&6 & $150 \%$ & $150 \%$ & $88 \%$ & \\
\hline & $15: 40$ & SFC-5\&6 & $33 \%$ & $12 \%$ & $11 \%$ & \\
\hline \multirow[t]{4}{*}{$8 / 8 / 91$} & $11: 00$ & SFC-5\&6 & $-36 \%$ & & $8 \%$ & \\
\hline & $11: 30$ & SFC-5\&6 & $57 \%$ & & $12 \%$ & \\
\hline & $17: 25$ & SFC-5\&6 & $89 \%$ & & $13 \%$ & \\
\hline & 18:05 & SFC-5\&6 & $50 \%$ & & $11 \%$ & \\
\hline \multirow[t]{2}{*}{$1 / 15 / 92$} & $9: 25$ & SFC-1\&2 & $28 \%$ & & $7 \%$ & $11 \%$ \\
\hline & $9: 15$ & SFC-5\&6 & $34 \%$ & & $8 \%$ & $16 \%$ \\
\hline \multirow[t]{3}{*}{$1 / 15 / 92$} & $13: 50$ & SFC-1\&2 & $29 \%$ & & $10 \%$ & $11 \%$ \\
\hline & 14:10 & SFC-3\&4 & $11 \%$ & & $10 \%$ & $10 \%$ \\
\hline & 14:00 & SFC-5\&6 & $42 \%$ & & $9 \%$ & $16 \%$ \\
\hline \multirow[t]{3}{*}{$1 / 16 / 92$} & $8: 00$ & SFC-1\&2 & & & $8 \%$ & $7 \%$ \\
\hline & $8: 15$ & SFC-3\&4 & & & $14 \%$ & $8 \%$ \\
\hline & $8: 30$ & SFC-5\&6 & & & $13 \%$ & $14 \%$ \\
\hline \multirow[t]{3}{*}{$1 / 16 / 92$} & $11: 50$ & SFC-1\&2 & & & $8 \%$ & $4 \%$ \\
\hline & $12: 00$ & SFC-3\&4 & & & $9 \%$ & $8 \%$ \\
\hline & $11: 40$ & SFC-5\&6 & & & $9 \%$ & $9 \%$ \\
\hline \multirow[t]{3}{*}{$1 / 16 / 92$} & $14: 15$ & SFC-1\&2 & & & $6 \%$ & $4 \%$ \\
\hline & $14: 25$ & SFC-3\&4 & & & $12 \%$ & $9 \%$ \\
\hline & 14:05 & SFC-5\&6 & & & $7 \%$ & $8 \%$ \\
\hline
\end{tabular}

Table 9: Comparison of percent outdoor air measurements by method

$\mathrm{CO}_{2}$ detector tubes did not yield reliable measurements of percent outdoor air intake due to the difficulty in obtaining consistent readings and the low resolution of the tubes. The single person $\mathrm{CO}_{2}$ tube method yielded results which were as much as several hundred percent different from the values obtained by the other tracer gas methods. For example, on 8 August 1991 and 15 January 1992 the automated SF 6 and $\mathrm{CO}_{2}$ systems yielded percent outdoor air intake rates under minimum outdoor air intake conditions of approximately $10 \%$, while the $\mathrm{CO}_{2}$ tube method yielded results from $-36 \%$ to $89 \%$.

As compared with the $\mathrm{CO}_{2}$ concentration measurements using the automated system, the measurements of $\mathrm{CO}_{2}$ concentrations with detector tubes in this study were associated with significant measurement errors. Large variations between readings taken by individuals occurred because the line separating the reacted and non-reacted chemical is diffuse, making it difficult to read the tubes consistently. Graduations on the tubes are in increments of $500 \mathrm{ppm}$ which is very coarse for resolving concentrations typical of indoor and outdoor air. Errors in the tube readings 
are magnified when calculating percent outdoor air intake, because the calculations involve differences between these uncertain concentrations. The outdoor readings obtained with the detector tubes were often high compared to readings taken at the same time by the infrared $\mathrm{CO}_{2}$ detector.

The three person method seemed to be useful only to determine a rough estimate of percent outdoor air intake, but it still yields some unreasonable results. Percent outdoor air values obtained using the three person $\mathrm{CO}_{2}$ detector tube sampling method correlated better with the outdoor air damper status than the values obtained by the single person method which did not correlate at all.

The percent outdoor air intake rates measured with the direct flow technique under minimum outdoor air intake conditions were approximately $5 \%$, which is about one-half of the intake rates determined with the automated $\mathrm{SF}_{6}$ and $\mathrm{CO}_{2}$ systems. The reason for this difference is that the direct airflow measurements only accounted for intake through the minimum outdoor air fans and did not account for leakage of outdoor air through the mixed-air dampers when they were in the fully closed position. Based on these results it is seen that under minimum outdoor air intake conditions outdoor air leakage through the mixed-air dampers is approximately equal to the intentional minimum outdoor air intake rate.

\subsubsection{Ventilation Rate per Person}

The outdoor air ventilation rate per person was determined using the $\mathrm{SF}_{6}$ decay technique, the analysis of peak $\mathrm{CO}_{2}$ concentrations based on the automated $\mathrm{CO}_{2}$ system and $\mathrm{CO}_{2}$ detector tubes, the multiplicative method based on the measurement of supply airflow rates and the various approaches to determining percent outdoor air intake, and the direct measurement of the outdoor air intake flow rate. The ventilation per person based on $\mathrm{SF}_{6}$ decay and peak $\mathrm{CO}_{2}$ analysis account for both outdoor air intake through the mechanical system and envelope infiltration. The other approaches to determining ventilation per person account for only mechanical outdoor air intake, with some of these approaches only accounting for intake through the minimum outdoor air intake fans.

Table 10 presents per person ventilation rates as determined from $\mathrm{SF}_{6}$ decay and peak $\mathrm{CO}_{2}$ concentrations determined with the automated $\mathrm{CO}_{2}$ measurement system. Under minimum outdoor air intake conditions, the $\mathrm{CO}_{2}$-based values are roughly twice those determined by $\mathrm{SF}_{6}$ decay. At higher air change rates, as expected, the difference is not quite as large though still significant. Under minimum percent outdoor air intake the tracer decay method yielded a ventilation rate of approximately $8 \mathrm{~L} / \mathrm{s}(16 \mathrm{cfm})$ per person and the peak $\mathrm{CO}_{2}$ method yielded about $15 \mathrm{~L} / \mathrm{s}(30 \mathrm{cfm})$ per person. Under maximum outdoor air intake conditions the tracer decay method yielded about $30 \mathrm{~L} / \mathrm{s}(60 \mathrm{cfm})$ per person and the peak $\mathrm{CO}_{2}$ method about $50 \mathrm{~L} / \mathrm{s}(100$ cfm) per person. 


\begin{tabular}{|c|c|c|c|}
\hline \multirow{2}{*}{ Date } & \multirow{2}{*}{$\mathrm{Hr}$} & $\begin{array}{c}\mathrm{SF}_{6} \\
\text { Decay }\end{array}$ & $\begin{array}{c}\text { Peak } \mathrm{CO}_{2} \\
\text { Auto }\end{array}$ \\
\hline & & $\begin{array}{c}\mathrm{L} / \mathrm{s} \\
\text { per person }\end{array}$ & $\begin{array}{c}\text { L/s } \\
\text { per person }\end{array}$ \\
\hline $7 / 27 / 95$ & 9 & 27 & 50 \\
\hline $7 / 30 / 95$ & 9 & 29 & 45 \\
\hline $7 / 31 / 95$ & 9 & 29 & 49 \\
\hline $8 / 01 / 95$ & 9 & 32 & 52 \\
\hline $8 / 01 / 95$ & 15 & 8 & 18 \\
\hline $8 / 02 / 95$ & 9 & 30 & 54 \\
\hline $8 / 13 / 95$ & 9 & 27 & 43 \\
\hline $8 / 13 / 95$ & 17 & 8 & 37 \\
\hline $8 / 14 / 95$ & 9 & 30 & 45 \\
\hline $8 / 15 / 95$ & 9 & 28 & 45 \\
\hline $8 / 15 / 95$ & 16 & 9 & 20 \\
\hline $8 / 16 / 95$ & 9 & 33 & 47 \\
\hline $8 / 16 / 95$ & 15 & 9 & 15 \\
\hline $8 / 17 / 95$ & 10 & 25 & 45 \\
\hline $8 / 20 / 95$ & 9 & 31 & 43 \\
\hline $8 / 20 / 95$ & 15 & 9 & 20 \\
\hline $8 / 21 / 95$ & 9 & 29 & 52 \\
\hline $8 / 21 / 95$ & 15 & 9 & 17 \\
\hline $8 / 22 / 95$ & 8 & 26 & 49 \\
\hline $8 / 22 / 95$ & 15 & 9 & 18 \\
\hline $1 / 16 / 96$ & 11 & 7 & 14 \\
\hline $1 / 17 / 96$ & 11 & 7 & 13 \\
\hline
\end{tabular}

Table 10: Comparison of ventilation rate per person measurements by method

As seen in other studies [Persily and Dols 1990], overprediction by the peak $\mathrm{CO}_{2}$ approach occurs because the $\mathrm{CO}_{2}$ concentrations are not at equilibrium at the time of the measurements. This and most other office buildings are only occupied by an approximately constant number of people at best from about 9:00 a.m. until 12:00 noon and from 1:00 p.m. until 5:00 p.m. This typical pattern is illustrated for this building in Figure 11 along with the outdoor $\mathrm{CO}_{2}$ concentration. As is the case in this building, this relatively short period of constant occupancy is further shortened by the implementation of flex-time schedules. Because of this short period of constant occupancy, the indoor $\mathrm{CO}_{2}$ concentration never attains steady state. Under constant occupancy, 3 hours are required to reach $95 \%$ of the steady state concentration at an air change rate of 1.0 ach and approximately 6 hours at a rate of $0.5 \mathrm{ach}$. Therefore, in this and other office buildings, it is unlikely that the peak $\mathrm{CO}_{2}$ concentration is an actual equilibrium value, leading to overpredictions of per person ventilation rates based on peak $\mathrm{CO}_{2}$ analysis. 


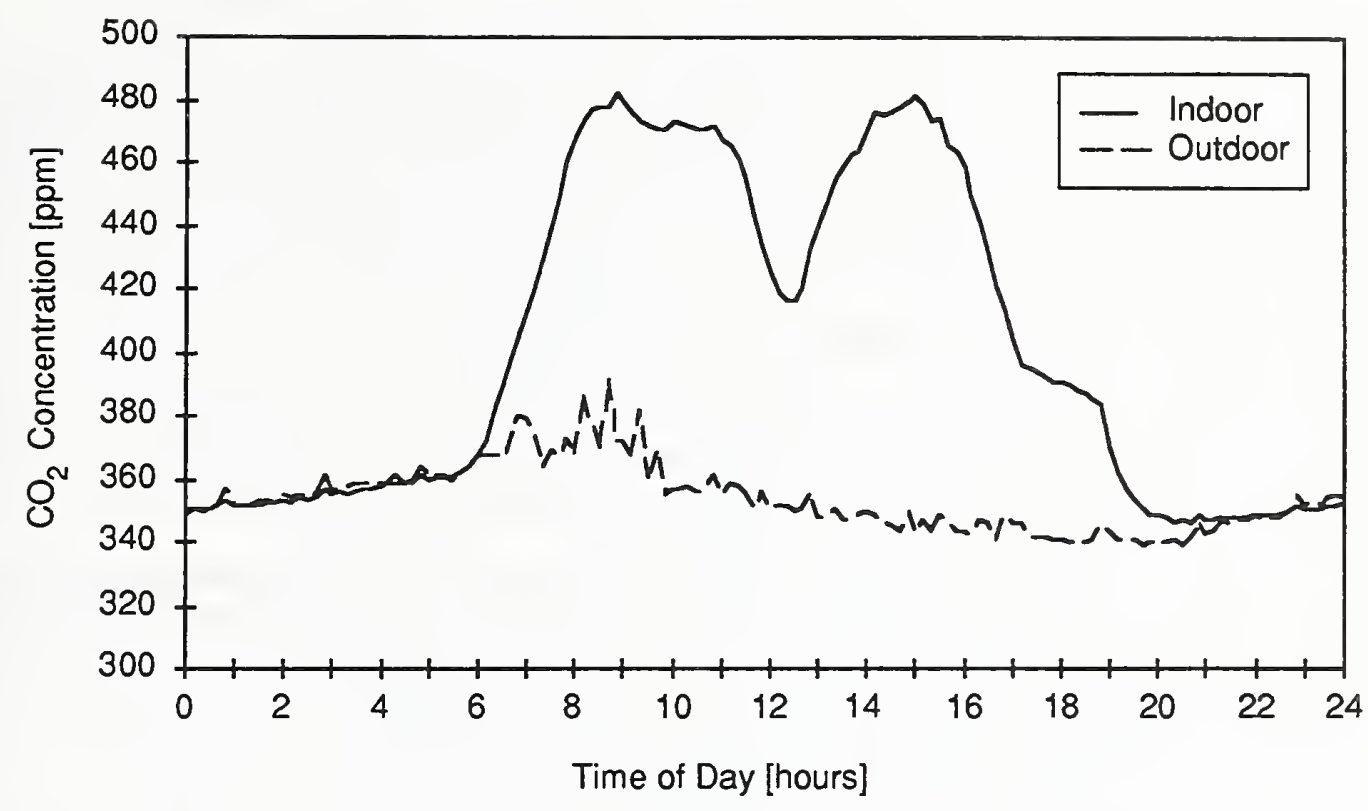

Figure 11: Typical daily pattern of $\mathrm{CO}_{2}$ concentration

The limited number of ventilation rate per person determinations based on peak $\mathrm{CO}_{2}$ with detector tubes agreed with the $\mathrm{SF}_{6}$ measurements, but this agreement was fortuitous. The peak $\mathrm{CO}_{2}$ approach with detector tubes has the same tendency to overpredict based on the use of preequilibrium concentrations. However, inaccuracies in the $\mathrm{CO}_{2}$ concentration measurements using the detector tubes just happened to balance out the preequilibrium overprediction.

Under minimum outdoor air intake, the multiplicative method of determining ventilation rate per person using percent outdoor air based on the automated $\mathrm{SF}_{6}$ and $\mathrm{CO}_{2}$ measurements agreed with the ventilation rate per person based on $\mathrm{SF}_{6}$ decay. This is interesting because the multiplicative method does not account for envelope infiltration, while the $\mathrm{SF}_{6}$ decay method does. The ventilation rate per person based on direct airflow rate measurement accounts for only intake through the minimum outdoor air intake fans, and the results of these determinations were about one half the results based on $\mathrm{SF}_{6}$ decay. Based on these results, the amount of envelope infiltration appears to be minimal under conditions of minimum outdoor air intake. However, there appears to be outdoor air leakage into the building through the mixed-air dampers at a rate approximately equal to the intake through the minimum outdoor air intake fan. This is consistent with the results of the percent outdoor air intake measurements. 


\subsection{Measurement Issues}

The approaches to ventilation assessment studied in this project have both advantages and disadvantages. The amount of effort associated with each technique, and the completeness and quality of the information obtained, is in general a function of the building being studied and the resources available to those performing the assessment. Building layout and HVAC system configuration are two important factors that impact the required level of effort. Additional resource requirements include the initial cost of the measurement equipment, the cost associated with installation, calibration and maintenance, the number of measurements to be conducted and the time for data analysis. The number of measurements is an important consideration when deciding between an automated monitoring system or a manual approach. This decision must involve a balance between the amount of time required to make the manual measurements and the installation time of an automated system. A discussion of some of these measurement issues follows, including estimates of the level of effort associated with each technique in this study.

$\mathrm{SF}_{6}$ Automated \& $\mathrm{CO}_{2}$ Automated - The initial set up of the automated $\mathrm{SF}_{6}$ and $\mathrm{CO}_{2}$ systems for measuring the concentrations at the main air handlers required about 10 person-weeks. However, these systems were installed for a different project, and if they were installed to conduct this study alone the installation would have required only about four person-weeks. Once the system was installed, the automated measurements required little effort to keep them running. Maintaining these systems involves calibrating the detectors, maintaining the sample pumps, valves and controllers within the systems, changing diskettes used to store the data, and replacing compressed gas cylinders. Calibration of the $\mathrm{SF}_{6}$ system takes about one hour, and the $\mathrm{CO}_{2}$ system takes about fifteen minutes. The $\mathrm{CO}_{2}$ system does not require a tracer gas injection system, it is easier and quicker to calibrate, and requires less maintenance than the gas-chromatograph based $\mathrm{SF}_{6}$ system.

Direct Flow - Direct airflow measurements require a detailed inspection of the HVAC system in order to identify the most suitable measurement locations. Once these locations are determined, the layout of traverse points must be determined and holes drilled in the ducts if necessary. As is often the case, recommended traverse locations for performing these measurements [ACGIH 1988] were unobtainable in this HVAC system. Traverses were performed in the only accessible locations with several different instruments, and the various approaches and measurement locations yielded similar results. Total supply airflow rates measured by performing duct traverses of the individual main supply ducts of all three systems required approximately 120 minutes to perform; whereas, measurements taken inside the fan boxes required only about 40 minutes to perform. Duct traverse measurements required about 60 minutes for all three minimum outdoor air intake fans. 
$\mathrm{CO}_{2}$ Tubes - Each measurement performed with a detector tube required approximately 10 minutes using three pump strokes per sample. A total of 60 minutes was required to measure per person ventilation rates at all three main air handlers. A similar amount of time was required to determine the percent outdoor air intake for the three air handlers. Depending on the circumstances, the $\mathrm{CO}_{2}$ concentrations may not be at equilibrium long enough to perform these measurements. $\mathrm{CO}_{2}$ detector tubes have the advantages of being portable and not requiring any installation time. Tube manufacturers state the tubes require no calibration; however, the tubes which were used in this study often disagreed with values determined with the infrared monitor used in the automated system. Results based on the $\mathrm{CO}_{2}$ tube measurements are subject to user interpretation and can yield very unreliable results when compared to a calibrated $\mathrm{CO}_{2}$ monitor.

$\mathrm{CO}_{2}$ Sample Bags - The use of air sample bags and portable pumps has the advantage over the use of an automated system of no installation time, except perhaps the drilling of access holes in the ductwork. In these tests, it took about one minute to collect the air samples and another minute to measure the $\mathrm{CO}_{2}$ concentration. Another option is to use a portable $\mathrm{CO}_{2}$ monitor at the measurement site. The monitor must be calibrated periodically, requiring about 15 minutes. This calibration time is relatively insignificant when performing a large number measurements. However, the use of a preequilibrium concentration will yield an overestimation of the ventilation rate.

$\mathrm{CO}_{2}$ build-up - This method was based on data collected by the automated $\mathrm{CO}_{2}$ sampling system. Because the data was collected automatically, the time required for this method was primarily associated with the nonlinear regression analysis. The build-up method also requires that the $\mathrm{CO}_{2}$ concentration data fit the model given by Equation 4. The limited amount of data analyzed in this study fit the model well, but as seen in other studies, this is not always the case [Persily and Dols 1990]. 
This study of ventilation assessment in an office building concentrated on two issues, changes in building ventilation characteristics over time and a comparison of different approaches to ventilation evaluation. In this study, whole building air change rates were measured over several months using the tracer gas decay technique. The results of these measurements were compared to a similar data set collected about three years earlier. This is the first time a detailed ventilation evaluation has been repeated over such a long period of time. There are several reasons one might expect building ventilation rates to change, such as calibration drift in the control system sensors, a lack of maintenance in other HVAC system components, changes in the building envelope leakage and intentional changes in building operation. These results indicate no significant changes in the ventilation rates of this building over time. The measured ventilation rates were always above the design minimum of $3 \mathrm{~L} / \mathrm{s}$ $(6 \mathrm{cfm})$ per person, in compliance with the recommendations of ASHRAE Standard 62-1981, the standard on which the design was based. The minimum ventilation rates were below the minimum levels recommended in ASHRAE Standard 62-1989 of 10 $\mathrm{L} / \mathrm{s}(20 \mathrm{cfm})$ per person. Ventilation rates per person ranged from about $7 \mathrm{~L} / \mathrm{s}(14$ $\mathrm{cfm})$ per person to about $36 \mathrm{~L} / \mathrm{s}(72 \mathrm{cfm})$ per person. Also, the measured air change rates indicate that the outdoor air intake controls are operating in accordance with design.

The measurements of ventilation system airflow rates using duct traverses showed that the minimum outdoor air intake was within 10 or $20 \%$ of design for the three minimum outdoor intake fans. Even though the traverse locations were not in accord with standard recommendations, the results of traverses using pitot tubes, hotwire anemometers and vane anemometers were generally within $10 \%$ of each other. In conducting these measurements, several logistical difficulties were identified such as inaccessible ductwork and modulations in system airflow rates during the traverses.

The determination of the percent outdoor air intake at the building air handlers was determined reliably using $\mathrm{SF}_{6}$ and $\mathrm{CO}_{2}$ balances in the supply, return and outdoor air streams. However, when $\mathrm{CO}_{2}$ detector tubes were used to perform these balances, the percent outdoor air determinations were inaccurate and unreliable. These problems were due to the inaccurate determinations of $\mathrm{CO}_{2}$ concentration using the detector tubes. The determination of percent outdoor air by dividing the measured outdoor air intake rate by the measured supply airflow rate yielded values approximately one-half of those obtained from the tracer gas mass balance under minimum intake conditions. This difference is due to outdoor air leakage into the building at the mixed air dampers under minimum outdoor air intake.

Ventilation rates per person were determined from whole building $\mathrm{SF}_{6}$ decay tests and equilibrium analysis of peak $\mathrm{CO}_{2}$ concentrations. The values obtained from the peak $\mathrm{CO}_{2}$ analysis were about $50 \%$ to $100 \%$ above the values obtained from $\mathrm{SF}_{6}$ 
decay, depending on the ventilation rate. This overprediction has been seen in other buildings and occurs because $\mathrm{CO}_{2}$ concentrations in office buildings rarely attain equilibrium due to insufficiently long periods of constant $\mathrm{CO}_{2}$ generation, i.e., constant occupancy. Ventilation rates can also be determined by multiplying measured supply airflow rates by percent outdoor air intake. When the percent outdoor air was determined by an $\mathrm{SF}_{5}$ or $\mathrm{CO}_{2}$ mass balance, the resultant ventilation rate was in good agreement with the rate obtained by $\mathrm{SF}_{6}$ decay. These ventilation rate determinations supported the finding that outdoor air was leaking into the building at the mixed air dampers under conditions of minimum outdoor air intake.

All of these approaches to ventilation evaluation have certain advantages and disadvantages, but none of them yield a complete characterization of the ventilation system performance. In order to obtain a complete understanding, a combination of methods must be considered and a certain investment of resources is required. In many situations, resource limitations result in the ability to perform only a partial evaluation of ventilation. However, with proper planning and careful consideration, a partial evaluation can still yield useful and reliable information.

In conducting a ventilation evaluation with any measurement approach, it is always necessary to begin by obtaining an understanding of the physical layout of the HVAC system as well as its operating schedule. The physical layout of the HVAC system should be determined using the most recent set of mechanical drawings available supplemented by a visual inspection of the system. The supply and outdoor air intake rate control strategies as well as design airflow rate specifications need to be obtained from fan schedules and control diagrams. Talking with the building HVAC engineers who operate and maintain the system is also essential to achieving this understanding of the system.

The ventilation measurements presented in this report involved only whole building air change rates and did not deal with the evaluation of the ventilation of individual floors or zones. While the methods discussed here are useful for determining compliance with ventilation standards and design values on a whole building scale, they do not address local performance issues. Ventilation assessment techniques applicable to the local scale are also needed, and additional research is required for their development and demonstration. 


\section{ACKNOWLEDGMENTS}

The authors would like to acknowledge the Bonneville Power Administration for their support of this research effort under Interagency Agreement No. DE-AI7991BP15148, with special thanks to Tim Steele of the Commercial Technology Section for his interest in this project. We also thank the building management staff for their logistical support, especially Jim McClain, Wayne Fuller and Doug VanNess. We also acknowledge the staff of Ogden Allied for their insight into the operation of the building mechanical system, especially Rich Clarke, Fred Krueger and Rick Jessup. 
ACGIH. 1988. Industrial Ventilation. A Manual of Recommended Practice, 20th edition, American Conference of Governmental Industrial Hygienists

Ancker, K., Göthe, C., and Bjurström, R. 1989. "Evaluation of $\mathrm{CO}_{2}$ detector tubes for measuring air recirculation." Environmental International, Vol. 15, pp. 605-608, 1989.

ASHRAE. 1981. ASHRAE Standard 62-1981, "Ventilation for acceptable air quality." American Society of Heating, Refrigerating, and Air-Conditioning Engineers, Inc.

ASHRAE. 1989a. ASHRAE Standard 62-1989, "Ventilation for acceptable air quality." American Society of Heating, Refrigerating, and Air-Conditioning Engineers, Inc.

ASHRAE. 1989b. ASHRAE Handbook of Fundamentals, American Society of Heating, Refrigerating, and Air-Conditioning Engineers, Inc.

ASTM. 1983. ASTM Standard E741-83, "Standard practice for measuring air leakage rates by the tracer dilution method." Philadelphia: American Society for Testing and Materials.

Grot, R.A., Persily, A.K., Hodgson, A.T., and Daisey, J.M. 1989. "Environmental evaluation of the Portland east federal office building preoccupancy and early occupancy results." NISTIR 89-4066, National Institute of Standards and Technology.

Persily, A.K., "Ventilation rates in office buildings," Proceedings of ASHRAE/SOEH Conference IAQ 89 The Human Equation: Health and Comfort, American Society of Heating, Refrigerating, and Air-Conditioning Engineers, Inc., Atlanta, 1989.

Persily, A.K., and Dols, W.S. 1990. "The relation of $\mathrm{CO}_{2}$ concentration to office building ventilation," Air Change Rate and Airtightness in Buildings, ASTM STP 1067, M.H. Sherman, Ed., American Society for Testing and Materials, Philadelphia, 1990, pp. 77-92.

Persily, A.K., and Norford, L.K. 1987. "Simultaneous measurements of infiltration and intake in an office building." ASHRAE Transactions, Vol. 93, Part 2, pp. 42-56. 



\begin{tabular}{|c|c|c|c|}
\hline \multirow{3}{*}{\multicolumn{2}{|c|}{$\begin{array}{l}\text { U.S. DEPARTMENT OF COMMERCE } \\
\text { NATIONAL INSTITUTE OF STANDARDS AND TECHNOLOGY }\end{array}$}} & \multicolumn{2}{|c|}{$\begin{array}{l}\text { 1. PUDUCATIOH OR REPORT NUMDEA } \\
\text { NISTIR } 4905\end{array}$} \\
\hline & & \multicolumn{2}{|c|}{ 2. PERFOAMINO OAQANIZA TION AEPOAT NUMDEA } \\
\hline & & \multicolumn{2}{|c|}{$\begin{array}{l}\text { 3. PUEUCATION DATE } \\
\text { OCTOBER } 1992\end{array}$} \\
\hline \multicolumn{4}{|c|}{$\begin{array}{l}\text { 4. TITLAND SUDTIRE } \\
\text { A Study of Ventilation Measurement in an Office Building }\end{array}$} \\
\hline \multicolumn{4}{|c|}{ 5. AUTHOn(\$) } \\
\hline \multicolumn{2}{|r|}{ 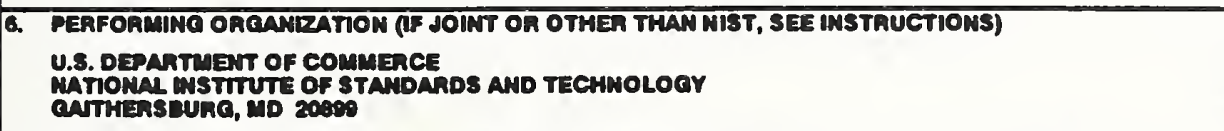 } & \multicolumn{2}{|c|}{ 7. CONTAACT/GAANT MUMSER } \\
\hline \multicolumn{4}{|c|}{$\begin{array}{l}\text { Bonneville Power Administration } \\
\text { Commercial Technology Section } \\
\text { Portland, OR } 97208\end{array}$} \\
\hline \multicolumn{4}{|c|}{ 10. SUPPLEMENTARY NOTES } \\
\hline \multicolumn{4}{|c|}{ 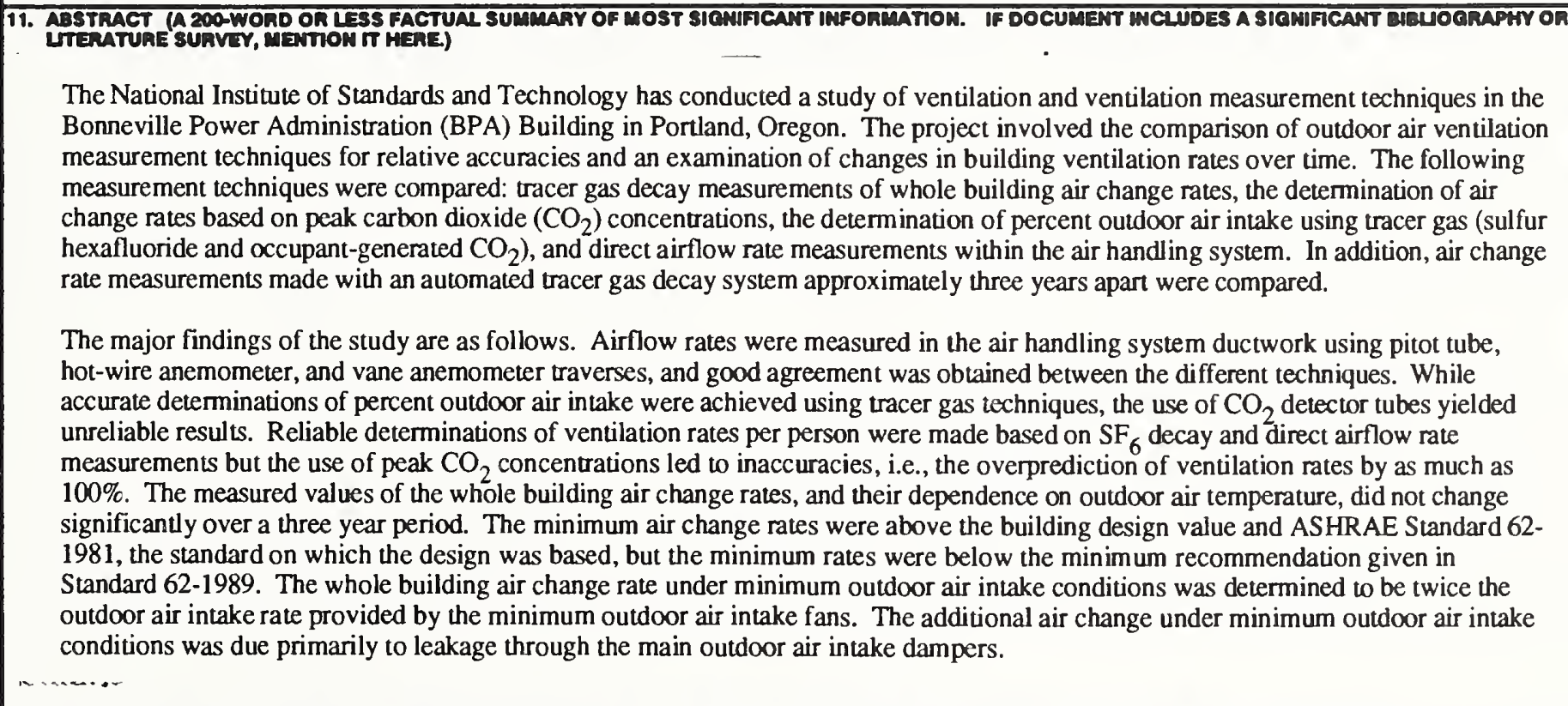 } \\
\hline \multicolumn{4}{|c|}{ 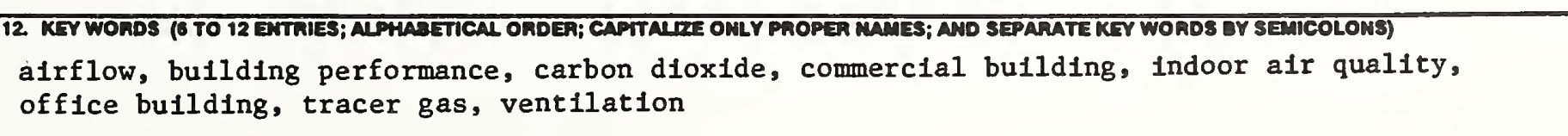 } \\
\hline \multirow[t]{2}{*}{ 13. AV } & \multirow{2}{*}{\multicolumn{2}{|c|}{ 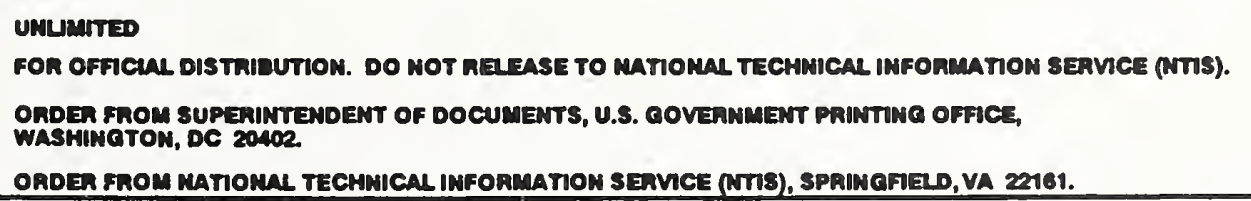 }} & 14. NUMBER OF PAINTED PAGES \\
\hline & & & $\begin{array}{r}\text { 15. PRICE } \\
\text { A03 }\end{array}$ \\
\hline
\end{tabular}



